\title{
Ehl-i Hadis Ders Halkalarının Tespitine Dair Bir Metot Teklifi: II. (VIII.) Asrın İlk Yarısı Basra Örneği*
}

\author{
Muhammed Enes Topgül ${ }^{* *}$ - Ömer Faruk Maden**
}

\begin{abstract}
Bu makale erken İslam toplumunda hadisle meşgul olan âlimlerin halkalarını ve ilmî çevrelerini netleştirmeyi hedefleyen üç aşamalı bir metot önerisinde bulunmaktadır. Zaman olarak II. (VIII.) asrın ilk yarısıyla, coğrafi olarak da Basra şehriyle kayıtlanan makalede söz konusu metodun gerekçeleri, dayanakları ve işletilme tarzı etraflıca sunulmuş, ardından metodun sunduğu sonuçlar hadis tarihi bakımından değerlendirilmiştir. İlgili metot temelde birbirini tamamlayan ve yer yer revize eden üç aşamadan oluşmaktadır. İlk aşamada rivayet metinlerindeki hadislerin isnadları tarihî bir veri olarak kullanılıp ilk halka şemaları çıkartılmıştır. Bu şemaların çıkarılması için birtakım temel tabakat ve rical kaynakları taranarak bir üst râvi kümesi oluşturulmuş, belli işlemlerle râvi kümesi daraltılmış ve ulaşılan alt râvi kümesindeki her bir isim Ahmed b. Hanbel'in el-Müsned'i ve Abdürrezzâk b. Hemmâm ile İbn Ebû Şeybe’nin el-Musannef'lerinin sınırlı sayıda isnadında taranmış, rivayet alıp veren şahısların irtibatlarının azlık ve çokluğuna göre râviler arasında hocalık-talebelik ilişkileri vazedilerek ilk halka şemalarına ulaşılmıştır. İkinci aşamada alt râvi kümesindeki her bir râvinin biyografisi rical kaynaklarında incelenmiş ve ilk aşamada tespit edilen hoca-talebe irtibatlarının isabeti test edilmiştir. $\mathrm{Bu}$ aşamada metodun birinci aşamasına bazı ilavelerde bulunulmuştur. Üçüncü ve son aşamada ise özellikle hadis usulü kaynakları hadis tarihinin temel bazı konuları çerçevesinde taranmış ve herhangi konuda aynı görüşü beyan eden âlimlerin arasındaki hoca-talebe irtibatı halka tespiti bağlamında değerlendirilmiştir. Mezkûr üç aşamanın ardından bir "Basra Hadis Halkaları" şemasına ulaşılmış ve bu bulgu aracılığı ile hadis tarihi hakkında birtakım tahlil ve tekliflere yer verilmiştir.
\end{abstract}

Anahtar kelimeler: Ehl-i hadis, hadis, Basra, hadis halkası, Hasan el-Basrî, Muhammed b. Sîrîn.

* Tarafımızdan geliştirilen bu metot ilk olarak Maden'in Hicrî II. Asır Ehl-i Hadîs Halkaları adlı yüksek lisans tezinde uygulanmış, bazı açlardan revize edilerek Topgül tarafından American Oriental Society'nin 229. toplantısında "Ahl al-hadith Circles of Bașra in the First Half of the $2^{\text {nd }} / 8^{\text {th }}$ Century" adıyla sunulmuştur (Chicago, 15-18 Mart 2019). Burada ise her iki çalışmadaki bazı noktalar ve veriler gözden geçirilerek metot yeniden arzedilmektedir.

** Doç.Dr., Marmara Üniversitesi İlahiyat Fakültesi Hadis Anabilim Dalı ORCID oooo-0003-3077-2610 enes.topgul@marmara.edu.tr

*** Arş.Gör., Marmara Üniversitesi İlahiyat Fakültesi Hadis Anabilim Dalı

ORCID oooo-0002-6208-3679 ofaruk@marmara.edu.tr 


\section{Problematik Bir Giriş}

Hadis tarihinin ilk üç asrını inceleyen ve çoğu zaman ders kitabı olma hedefiyle kaleme alınan çağdaş çalışmalar genellikle kronolojik bir seyir izler. Bundan dolayı hadis tarihinin aslında çok daha sonraları gündeme gelecek birçok probleminin izi ya Hz. Peygamber'in hayatı ya da sahabe döneminden örneklerle temellendirilmeye çalışılır. Haber-i vâhid tartışmaları, sünnetin dindeki delil değeri, hadislerin Kur'an'a arzı, ilim yolculukları (rihle), manen rivayet ve hadis yazımı (kitâbetü̉l-hadîs) gibi bazıları özellikle II. (VIII.) asır bağlamında anlamlı olan meselelere dair klasik kaynaklardaki anlatılar makul bir tarihî çerçeveye kavuşturulmak yerine geriye dönük bir tarih inşasının aracı kılınır. Tarih yazımı esnasında ana akım ekollerin bölgelerine dair silik bir bilinç varsa da ${ }^{1}$ ilim merkezlerinin (emsâr) kendilerine özgü yönleri, ilmi icra tarzları ve kendi içlerindeki farklılıkları yeterince incelemeye konu olmamıştır. Mesela -mahiyetine ileride değinilecek olan- ehl-i hadisin Yemen, Dımaşk ve Mısır bölgelerindeki durumu hiç ele alınmamış, Kûfe ile Basra üzerine yapılan Türkçe ve Arapça çalışmalar ise ${ }^{2}$ klasik bir tabakat kitabı görüntüsünü ancak birkaç konuda aşabilmiştir. ${ }^{3}$ Ayrıca erken İslam toplumundaki düşünce akımlarının bölgesel farklılıkları hakkındaki tahkiyeler de ancak çok temel bilgiler üzerinden yapılmıştır (Bağdat ve Basra Mu'tezilesi’ne dair olanlar gibi).

Müstakil bir monografisi kaleme alınmayan ehl-i hadisin dönemsel ve bölgesel farklılıklarının ${ }^{4}$ ciddi bir ilgiye mazhar olmaması, ${ }^{5}$ hadis tarihinin birtakım problemleri hakkında varılan yargıların genellemelere dayanması

1 Ehl-i re’yin Kûfe, ehl-i hadisin Hicaz merkezli olduğu yönündeki bazı açılardan revizeye muhtaç görüş bu bağlamda zikredilebilir (konu hakkındaki bir tartışma için bk. Melchert, "Hanefîliğin Kûfe ve Ehl-i Hadis'in Medine Kökenli Olarak Algılanması", s. 167-204).

2 Mezkûr çalışmalara örnek olarak bk. Kuzâh, Medresetü'l-hadîs fi'l-Basra; Kahraman, Kûfe'de Hadis; Çelik, İlk Üç Asırda Basra'da Hadis İlmi.

3 Basra ve Kûfe ders halkaları ile bu halkaların rivayet tarzı, hadis meseleleri ve en önemlisi hadis tarihi bakımından anlamları, burada vazedilen metot çerçevesinde, doktora düzeyinde sırasıyla Ömer Faruk Maden ve Muhammet İkbal Aslan tarafından; Dımaşk, Yemen ve Medine hadis halkaları da aynı metot çerçevesinde yüksek lisans düzeyinde, sırasıyla Adem Sari, Hatice Demirci ve Rıdvan Talha Yücedağ tarafından çalışılmaktadır. İlgili tezlerin tamamı II. (VIII.) asır çerçevesindedir.

4 Ehl-i hadisi olmasa da hadis tarihini coğrafya merkezli bir okumaya tâbi tutmayı hedefleyen bir çalışma için bk. Akgün, Hadis Rivâyet Coğrafyası.

5 Ehl-i hadisi daha ziyade itikadî açılardan ele alan bazı çalışmalar için bk. Kutlu, Selefiliğin Fikrî Arka Planı (Bu kitap daha önce şu başlıkla yayımlanmıştır: İslam Düşüncesinde İlk Gelenekçiler: Hadis Taraftarlarının İman Anlayışı Bağlamında Bir Zihniyet Analizi, Ankara: Kitâbiyât, 200o); Gürler, Ehl-i Hadisin Düşünce Yapısı; Kırbaşoğlu, Ehl-i Sünnet'in Kurucu Ataları. 
sonucunu doğurmaktadır. Mesela hem Mâlik b. Enes (ö. 179/795) hem de Şâfî (ö. 204/820) ve Ahmed b. Hanbel (ö. 241/855) bir şemsiye kavram olan ve sınırları tam olarak çizilemeyen ${ }^{6}$ ehl-i hadis içerisinde değerlendirilebilir. Ancak onların yaklaşımları daha yakından incelendiğinde tahmin edilenin ötesinde metodik farkların varlı̆̆ dikkat çeker. Nitekim II. (VIII.) asırda çok canlı olan amel etrafındaki tartışmalar zaman ilerleyip de amelin mahiyeti değişince önemini yitirmiştir. Önce şehirler arası bilgi akışı düzenli bir hal almış, ardından Leys b. Sa'd (ö. 175/791) ve Muhammed eş-Şeybânînin (ö. 189/905) yanı sıra Şâfiînin ısrarlı metodik hücumlarından sonra şehir amellerine dair telakki değişmiş ve dolayısıyla Hicaz ve diğer şehirlerin amellerine yapılan vurgu zayıflamıştır. ${ }^{7}$ Özetle amel konusu Mâlik b. Enes ile Şâfî̀nin yaklaşımlarındaki temel bir farklılıktır. Kısmen Şeybânînin ama ağırlıklı olarak Şâfiînin vurguları sonucu hadis algısında meydana gelen değişiklik de aynı dönemde tezahür etmiştir. Merfû-muttasıl olma şartının sıhhat meselesinin merkezine yerleşmesi sonucunda II. (VIII.) asır metinleri -en azından hadisçiler açısından- işlevselliğini yitirmiş ve belki de yegâne önemleri III. (IX.) asır metinlerine kaynaklık etmeleri olmuştur. III. (IX.) asrın başlarında ise Şaffî̀nin, sünneti merfû hadis ile aynîleştiren yaklaşımının sonucunda "müsned" türü ortaya çıkmıştır. Hasıll, ekollerin kendi içindeki değişim ve farklılıkları ile bunların hadis meselelerine, ilmî üretim tarzlarına ve muhatapları değerlendirme yaklaşımlarına etkisinin göz ardı edilmesi, özelde hadis tarihi, genelde ise İslamî ilimler tarihi yazımı açısından ciddi bir sorun teşkil etmektedir.

$\mathrm{Bu}$ makale, temelde hadis tarihi yazımı için ihtiyaç duyulan özel ve derinlikli etütlere bir örnek olmak üzere, "Basra ehl-i hadisinin II. (VIII.) asrın ilk yarısındaki durumunu hadis halkaları çerçevesinde tespit etmeye yarayan bir metot önerisi”nde bulunmaktadır. Aynı zamanda ehl-i hadisin o dönem ve coğrafyadaki çoklu yapısını göstermeyi, diğer yandan özellikle manen hadis rivayeti ve kitâbetüll-hadîs gibi temel tartışma konularındaki genel nitelikli bazı yargıları revize etmeyi amaçlamaktadır. Ayrıca makalenin ülkemizde özellikle yüksek lisans seviyesinde çalışılan ve teoride hadis tarihinin aydınlatılması açısından son derece önemli olmasına rağmen bu misyonu genellikle icra edemeyen ve hatta incelenen âlim/muhaddisin yaşadığı za-

6 Ehl-i hadisin tespitinin izafiliğine dair bir görüş için bk. Özşenel, İlk Dönem Hadis-Rey Tartışmaları, s. 126-32.

7 II. (VIII.) asırda Medine’nin yanı sıra Kûfe ve Şam gibi şehirlerde de etkili olan amel düşüncesinin zayıflamasının temel sebepleri olarak amelin zamanla aslî hüviyetini yitirip tahrifata maruz kalması ve istikrar kazanan amelin sözlü veya yazılı kaynaklara aktarılmak suretiyle fiil formundan çıkıp farklı bir forma bürünmesi zikredilmektedir (Özkan, Hicrî İlk İki Asırda Farklı Şehirlerde Amel Telakkisi, s. 308). 
man dilimini anlamayı zorlaştıran şahıs merkezli çalışmalar için de bir yol haritası olması umulmaktadır.

Makale boyunca incelenecek meselelerde dikkat çekilmesi gereken nokta, genelde halka tespiti, özelde bir râvinin entelektüel biyografisinde son derece önemli olan hocalarının ve talebelerinin belirlenmesinde etkin bir şekilde kullanılan biyografik malzemenin ve rivayet verilerinin tamamının kaynaklarda dağınık da olsa bulunduğu gerçeğidir. Usul eserlerinin durumu ise biraz farklıdır. Zira bu eserler konu merkezli bir kurguya sahip olduğu için spesifik bir meselede farklı kanaat serdedenleri gruplayarak bir arada sunar. $\mathrm{Bu}$, araştırmacıya görece bir kolaylık sağlasa da mezkûr kaynaklardan etkili bir şekilde istifade etmek, ancak ilgili konunun hadis tarihindeki gelişmelerle irtibatlı olarak incelenmesine bağlıdır. Bu çalışma bölgesel ve dönemsel hadis halkalarına dair bir bilinç olduğunda ve uygun sorular sorulabildiğinde rical kaynaklarının ve usul eserlerinin daha aktif biçimde ve bir arada kullanılabileceğini, özellikle de isnadın hadis tarihi açısından nasıl okunabileceğini göstermeyi de hedeflemektedir.

Son olarak çağdaş dönem çalışmalarında ehl-i hadisin ele alınma biçimine değinilmelidir. İlgili çalışmalar incelendiğinde meselenin daha ziyade ehl-i hadis ve ehl-i re’y farklılığ çerçevesinde ele alındığı görülür. Ehl-i hadisin kendi içindeki farklılıklarına dair nadir anlatılardaysa fikıh merkezli bir bakış açısı dikkat çeker. Ehl-i hadis âlimlerinin fikhî konulardaki metot farklılığı, görüşlerini dayandırdıkları otoriteler ve bunların ehl-i re'yin otoriteleriyle kıyaslanması ve genel kabule göre Şâfiî sonrasında ehl-i hadisi etkisi altına alan "merfû hadis vurgusu"nun test edildiği ilgili çalışmalarda$\mathrm{ki}^{8}$ hareket tarzı bu çalışmadakinden oldukça farklıdır. Hem bu çalışmalarda incelendiği şekliyle hem de itikadî bakımdan ehl-i hadisin kimliğinin tespiti meselesi hâlâ önemini korumaktadır.

Erken dönem ilim merkezlerindeki hadis halkalarının tespitinde uygulanacak yöntemi göstermeyi hedefleyen bu çalışmada öncelikle makalenin kendisi boyunca takip edilen metot genel hatlarıla anlatılacaktır. Ardından bu metodun II. (VIII.) asır Basra’sında yaşamış ehl-i hadis mensupları örneklemi üzerindeki uygulamasına yer verilecektir. Uygulamada sırasıyla isnad, rical ve usul kaynaklarından elde edilen bilgiler etkin ve birbirini tamamla-

8 Meseleye bakışları açısından zaman zaman farklı sonuçlara ulaşan mezkûr çalışmalardan bazıları için bk. Melchert, The Formation, s. 1-31; Spectorsky, "Hadith in the Responses of Ishạq b. Rāhwayh"; Hallaq, Origins, s. 74-76, 102-109, 113-28; Lucas, "Where are the Legal Ḥadith?". Brown'un konuya bakışıysa fikhî olmaktan çok "hadislerin lafzî ve tarihsel gerçekliğine" dönük farklılıklara yöneliktir (bk. "Did the Prophet Say It or Not?"). 
yacak ve/veya tashih edecek şekilde kullanılacaktır. Son olarak metodun hadis tarihini anlamak adına sunduğu avantajlar ve metot etrafındaki birtakım sorunlar tartışma ve sonuç kısmında ele alınacaktır.

\section{Metot ve Uygulama}

İncelenecek dönemde ehl-i hadis terkibi farklı eğilimleri içerisine alan şemsiye bir terim olarak kullanılmakta ise de daha ziyade hadis nakil faaliyetleriyle ilgilenen ve dinî metinleri anlamada göreceli de olsa nasların zâhiriyle yetinen grubu ifade etmektedir. Ortaya çıkış dönemi hakkında farklı görüşler olan bu ekolün mukabilinde ise ehl-i re’y olarak anılan grup yer almaktadır. Bununla birlikte çalışmada kullanılan "ehl-i hadisin ders halkaları" tabiri ile bütün bir ehl-i hadis halkaları ya da cerh-ta'dil yahut ilel gibi teknik konuların konuşulduğu özel nitelikli ihtisas halkaları değil, genellikle sinırlı sayıda hadis hocasından nakilde bulunan kimselerin ders meclisleri, yani semâ halkaları kastedilmektedir. Zira makaleye konu olan zaman diliminin en azından başları, hadis rivayetinin yeni yeni sistemli bir hal aldığ bir dönemdir. Özellikle 100'lerden (720) sonra semâ, 130'lardan (750) sonra ise cerh-ta'dil halkaları ortaya çıkmış ve kısa bir süre sonra düzenli bir hal almıştır. Ancak her hâlükârda II. (VIII.) asrın ilk yarısında bir meşguliyet alanı olarak hadis denildiğinde daha ziyade birtakım rivayetlerin derlenip nakledilmesi faaliyeti anlaşılmaktadır. Mahza hadis rivayetiyle uğraşanların çokluğuna mukabil mesela hadisleri fikhî konulara göre tasnif etme ya da cerh-ta'dil ile meşgul olma gibi ilmî faaliyetlerle meslekî olarak ilgilenen muhaddislerin sayısı ise bütün bir II. (VIII.) asırda iki elin parmaklarını geçmemektedir. ${ }^{9}$

Çalışma, dönem olarak II. (VIII.) asrın ilk yarısıyla kayıtlanmıştır. Bunun en temel sebebi II. (VIII.) asrın tamamının kapsama dahil edilmesinin doğuracağı teknik ve iş yükü zorluklarıdır. Ayrıca düzenli rihle faaliyetleriyle şehir amellerinin peyderpey ortadan kalkması, her bir rivayetin farklı şehirlere intikali, ekoller arası tartışmaların artması ve mahiyet değiştirmesi ile siyasi etkiler gibi etkenlerden dolayı II. (VIII.) asrın ikinci yarısının buradakilerden nispeten farklılaşan sorularla incelenmesi gereklidir. Burada sunulacak metodun en azından ehl-i hadisin II. (VIII.) asrın ilk yarısındaki ders halkalarını tespite ve çözümlemeye imkân vereceği öngörülmektedir.

II. (VIII.) asırdaki pek çok şehir arasından niçin Basra’nın seçildiği de izah edilmelidir. Bu zaman diliminde Basra’nın yanı sıra Kûfe, Mekke ve Medine

9 II. (VIII.) asırda düzenli olarak cerh-ta'dil faaliyetinde bulunan kimseler ve faaliyetleri için bk. Turhan, Ricâl Tenkidinin Doğuşu ve Gelişimi, s. 115-454. 
gibi şehirler ile Mısır, Şam ve Yemen gibi bölgelerde de birtakım faaliyetler yürütülüyordu. Yemen istisna edilecek olursa Basrảnın Kûfe ve Medine ile birlikte ilmî bakımdan önde gelen şehirlerden biri olduğu farklı çalışmalarda gösterilmiştir. ${ }^{10}$ Basra’nın seçilmesi hem konuyu sınırlandırma hedefine matuftur hem de Kûfe'deki "fikıh merkezli düşünme" ve Medine'deki "ameli dinî bilginin merkezine yerleștirme" tavırlarına mukabil rivayet eksenli anlayışın Basra’da daha baskın olmasından kaynaklanmaktadır.

Makalede ders halkalarının belirlenmesinde isnad verilerinin tespiti, rical verilerinin tespiti ve tematik verilerin tespiti şeklinde üç aşamalı bir metot önerilecektir. Her aşamada bir önceki aşamada ulaşılan sonuçlar doğrulanacak ya da tashih ve revize edilecektir. İsnad verilerinde öncelikle Ahmed b. Hanbel'in daha ziyade Kûfe ve Basra bilgi birikimini sunan el-Müsned'i merkeze alınacak, bu eserden elde edilen veriler ise Abdürrezzâk es-Sanânînin (ö. 211/827) Mekke, Basra ve Kûfe, Ebû Bekir İbn Ebû Şeybe’nin (ö. 235/849) Kûfe ve Basra birikimini yansitan el-Musannefleri ile kontrol edilecektir. Böylece öne çıan karakterler ve bunların hoca-talebe ilişkileri isnadlar üzerinden tespit edilmiş olacaktır. İkinci aşamada bu veriler tarih, tabakat ve rical kaynaklarının ayrıntılı bir şekilde taranması neticesinde ulaşılan sonuçlarla karşılaştırılacaktır. Son aşamada ise "tematik bir yaklaşım" sergilenerek dönemin tartışmalı konularında tarafların ortaya koyduğu görüşler halka tespiti bağlamında değerlendirilecektir. Aşağıda ayrıntısıyla ele alınacak bu üçlü tasnifin II. (VIII.) asrın ilk yarısındaki Basra ehl-i hadis halkalarını büyük oranda netleştireceği düşünülmektedir.

\section{A) İsnad Verileri}

İsnad verilerinin tahliline geçmeden önce bir hususa dikkat çekmek gereklidir. İlimler tarihine dair klasik ve modern anlatılarda her bir şehrin ilim anlayışının fetihler ve daha başka sebeplerle o beldeye giden sahâbîler üzerinden şekillendiğine yönelik yaygın bir kabul söz konusudur. Zaten sahabenin yaygın olarak yaşadığı Medine ile Kûfe gibi şehirler için büyük oranda doğru kabul edilebilecek bu yargı Basra söz konusu olduğunda çeşitli noktalardan tenkide açıktır. Mezkûr anlatılarda Basrảnın rivayet ve ilim birikimi büyük oranda Ebû Mûsâ el-Eş'arî (ö. 42/662-3), Ebû Bekre (ö. 51/671 [?]), İmrân b. Husayn (ö. 52/672), Semüre b. Cündeb (ö. 60/680) ve özellikle Enes

10 İlgili iddiayı destekleyen bir tespit için bk. Cohen, "The Economic Background and the Secular Occupations", s. 44. Dijital beşeri ilimlerdeki (digital humanities) çalışmalarıyla dikkat çeken Maxim Romanov'un bulguları için bk. https://maximromanov.github. io/2014/o8-23.html (erişim: 17.06.2020). Konuya dair yapılmış yakın zamandaki bir çalışma için bk. Topgül, “Nisbeler”, s. 13-17. 
b. Mâlik (ö. 93/711-2) gibi sahâbîler üzerinden anlatılır. ${ }^{11}$ Ancak rivayet malzemesi incelendiğinde, bu sahâbîlerden sadece Enes b. Mâlik'in, üstelik o da yarı sistemli rivayette ${ }^{12}$ bulunarak ön plana çıktığı ve Basra hadis halkalarının büyük oranda Medine’ye ve hatta özellikle de Ebû Hüreyre’ye (ö. 58/678) dayandığı görülür. Dolayısıyla şehirlerin rivayet birikimini ve ilim anlayışlarını -en azından Basra özelinde- genellikle sahâbîler üzerinden değil, tâbiî râviler üzerinden anlamaya çalışmanın daha dakik sonuçlar vereceği söylenebilir. Mezkûr sebeplerden dolayı bu çalışmada Basra hadis faaliyetleri tâbiîn âlimleri ile başlatılacaktır.

Hadis tarihi açısından çok daha işlevsel bir rol ifa edebilecek isnad verilerinin, halka tespitinin ilk adımı olarak belirlenmesi tavrının İslamî ilimler geleneğine dayandığı özellikle belirtilmelidir. Zira Bağdatlı hadis hâfızı Ali b. Medînînin (ö. 234/849) İlelül-hadîs' indeki "İsnadları inceleyince onların altı isim etrafında döndügünü gördüm” (nazartü fe-ize'l-isnâdu yedûru alâ sitte) şeklindeki ifadesi onun hadis tarihinin kilit isimlerini, yani medar şahsiyetleri tespitte neredeyse tamamen isnada dayandığını açıkça göstermektedir. ${ }^{13}$ Onun bu araştırma tarzının, yani isnad üzerinden merkezî isimleri tespit etme faaliyetinin sonraki âlimlerce ne oranda tahlil ve takip edildiği ise ayrıca incelenmelidir. İbnü'l-Medînînin gündeme getirdiği medar isimler olgusunun Nesâî (ö. 303/915), -Sahîhayn merkezli olarak- Ebû Abdullah İbn Mende (ö. 395/1005) ve İbn Hibbân (ö. 354/965) tarafından birtakım değişikliklerle "şehirlerin merkezî isimlerini ve fakihlerini tespit etmek" üzere sunumu da hadis tarihi açısından incelenmeye muhtaçtır. ${ }^{14}$

İsnad verilerinde Abdürrezzâk es-Sanânînin ve İbn Ebû Şeybe’nin elMusannefleri ile Ahmed b. Hanbel'in el-Müsned'inin esas alınması ise bunların görece çok sayıda rivayet içermesinden dolayıdır. Zira hoca-talebe ilişkilerinin tespitinde Şâfî̀ sonrasında belirginleșen ve Buhârî ile (ö. 256/870) Müslim'in (ö. 261/875) es-Sahîh'lerinde en nitelikli kullanımları görülen istikrar bulmuş sıhhat kriterlerini benimseyen eserler yerine, bu tarz bir hedefi olmayan eserleri merkeze almak olabildiğince çok rivayete ulaşmak açısından daha işlevseldir. ${ }^{15}$ İkinci olarak Kütüb-i Sitte gibi hem yukarıdaki

11 Akgün, Hadis Rivâyet Coğrafyası, s. 128.

12 Sistemli ve yarı sistemli hadis rivayeti kavramları için bk. Kuzudişli, Hadis Tarihi, s. 103-106.

13 Onun ifadeleri ve medar listesi için bk. Ali b. Medînî, İlelü'l-hadîs, s. 76 vd.

$14 \mathrm{Bu}$ olgunun fikhü'l-hadîs çerçevesinde tahlili için bk. Yıldız, İlmî Bir Disiplin Olarak Fikhü'l-Hadîs, s. $115 \mathrm{vd}$.

15 Esas aldığımız neşirlere göre bu eserlerdeki rivayet sayıları mükerrerler dahil şu şekildedir: Ahmed b. Hanbel'in el-Müsned'inde 27647, Abdürrezzâk'in el-Musannef inde 21033, İbn Ebû Şeybe’nin el-Musannefinde 39098 rivayet yer almaktadır. Oysa 
kitaplara göre daha az rivayet ihtiva eden hem de kendine has hadis kabul kriterleri olan eserler hoca-talebe ilişkisini tespitte her zaman doğru sonuç vermeyebilir. Nitekim Basra hadisçiliğinin önemli isimlerinden Yahyâ b. Ebû Kesîr'in (ö. 129/747) hoca-talebe ilişkileri Buhârînin el-Câmiu's-sahîh'i ile Ahmed b. Hanbel'in el-Müsned' indeki rivayet malzemesi çerçevesinde incelendiğinde her iki kaynakta da Yahyầnın öne çıkan hocasının Ebû Seleme b. Abdurrahman b. Avf (ö. 94/712-3), en yakın talebelerinin ise Hişâm edDestüvâî (ö. 153/770) ve Evzâî (ö. 157/774) olduğu görülür. Bu örtüşmenin sebebi büyük oranda Yahyânın hocalarının ve talebelerinin güvenilir kimseler olmasıdır. Ancak bir başka Basralı tâbiî Sâbit el-Bünânînnin (ö. 127/744) hoca-talebe ilişkilerine bakıldığında durum farklılaşır. Zira iki kaynakta da Sâbit'in en çok istifade ettiği hocası Enes b. Mâlik iken en yakın talebesi konusunda farklılık vardır. Buhârîdeki verilere göre Sâbit'in en yakın talebesi Hammâd b. Zeyd (ö. 179/795) iken Ahmed'deki verilere göre Hammâd b. Seleme'dir (ö. 167/784) ve diğer rivayet kaynakları ve rical metinleriyle ${ }^{16}$ uyum arzeden sonuç da budur. Ayrıca bilindiği üzere Buhârî, el-Câmiu'ssahîh'inde Hammâd b. Seleme rivayetlerine sadece mütâbaat kabilinden yer vermiştir. Bu iki örnekte de görüldügü gibi ihtisar cihetiyle yazılan ve sıhhat kriterlerinin üst düzeyde işletildiği Buhârînin eserinden yola çıkarak yargıda bulunmak bizim konumuz açısından isabetli olmayacaktır. Bundan dolayı herhangi bir sıhhat şartı gözetmeksizin imkân nispetinde çok rivayeti bir araya getiren eserlerin tercihi bu tarz bir analiz için daha anlamlıdır.

İsnad verilerinin değerlendirilebilmesi için II. (VIII.) asırda Basra’da yaşamış 1500 kadar râvinin daraltılarak bir örneklem kümesi haline getirilmesi gerekmektedir. Bunun için birkaç kademeli bir işlem gerçekleştirilmiştir. Öncelikle eserlerinde Basralı râvilere özel bölümler tahsis eden erken dönem "tabakat" türü kitaplardan İbn Sa'd (ö. 230/845) ve Halîfe b. Hayyât’n (ö. 240/854-5) eserleri ${ }^{17}$ ile "rical" kaynaklarından Yahyâ b. Maîn’in (ö. 233/848)

Buhârî̀deki rivayet sayısı mükerrerlerle 7563, tekrarlar düşüldüğünde ise 2500 civarındadır. el-Musanneflerdeki sayısal fazlalığın en belirgin sebebi bu eserlerin mevkuf ve maktû rivayetleri de içermesidir.

16 Sâbit'in rivayetlerinde en güvenilir kimsenin Hammâd b. Seleme olduğuna dair bazı nakiller için bk. Ahmed b. Hanbel, el-İlel, II, 131; III, 268.

17 İbn Sa'd ve Halîfe b. Hayyât'ın eserleri rical kaynaklarında tespit edilemeyen pek çok râviye ulaşma imkânı sağlamıştır. Öncelikle ismi geçen rical eserleri cerh-ta'dil ve ilel ağırlıklı bilgiler içerdiği için sahabe tabakasına dair çok az bilgi barındırır. İbn Sa'd ve Halîfe b. Hayyât’ın "tabakat" türündeki çalışmaları sayesinde ise hadisle ilgisi daha zayıf kimselerin ilavesiyle olsa da üst örneklem kümesi sayıca genişletilebilmiştir. Ayrıca İbn Sa'd'ın eseri özellikle tematik veriler açısından zengin bilgiler ihtiva etmektedir. Halîfe b. Hayyât'ın metni daha ziyade nisbe ve vefat tarihi bilgisi açısından değerli ise de hoca-talebe ilişkilerine dair neredeyse hiçbir bilgi içermez. 
et-Târîh'i ve Ebû Dâvûd'un (ö. 275/889) Suâlât'nın ilgili bölümleri, müstakil bir bölüm altında olmasa da Basralı râvilere ilişkin değerli bilgiler içeren Ahmed b. Hanbel'in el-îlel' i dikkatli bir gözle okunmuştur.

Çalışmanın en çok iş yükü gerektiren aşaması da bu ilk râvi kümesinin ortaya çıkarılması olmuştur. Sonuç itibariyle yapılan bu ilk taramanın ardından yaklaşık 900 râviden oluşan bir üst örneklem kümesi elde edilmiştir. Mezkûr râvilerin isim, künye ve lakapları, kabile, şehir ve meslek nisbeleri, doğum ve vefat tarihleri, İbn Hacer'in sistemine göre tabakaları, mevlalık durumları, Basra dışındaki şehir ve bölgelere yolculukları, hadis dışında uğraştığı başka ilmî faaliyetler, cerh-ta‘dil durumları, hoca talebe ilişkileri ve biyografisine dair bilgiler farklı kısımlara ayrılmış bir tabloya girilmiştir. ${ }^{18}$ Ancak her bir râviye dair bu bilgilerin tamamı, zikredilen çalışmalardan elde edilmemiş, farklı aşamalarda diğer rical kaynaklarından istifadeyle mezkûr veriler olabildiğince tamamlanmıştır. Tablodaki özellikle kimlik, nisbe ve mevlalık verileri başka bir çalışmada kullanılmıştır. ${ }^{19}$ Bu makalede daha ziyade hoca-talebe ilişkilerine işık tutan ham verilerden hareketle ortaya konan çıkarımlar tartışılacaktır. Öncelikle, bu kısımda yer alan râvilerin hocatalebe ilişkilerinin tamamı dikkate alındığında en çok anılan muhaddisler şu yirmi üç kişidir:

İmrân b. Husayn, Semüre b. Cündeb, Enes b. Mâlik, Hasan el-Basrî (ö. 110/728), Muhammed b. Sîrîn (ö. 110/729), Humeyd b. Hilâl (ö. 120/737-8 civarı), Katâde b. Diâme (ö. 117/735), Sâbit el-Bünânî, Yahyâ b. Ebû Kesîr, Eyyûb es-Sahtiyânî (ö. 131/749), Ali b. Zeyd b. Cüdân (ö. 131/748-9), Hâlid el-Hazzâ (ö. 141/758-9 [?]), Humeyd et-Tavîl (ö. 143/760), Saîd b. İyâs elCüreyrî (ö. 144/761), Avf el-A'râbî (ö. 146/763 [?]), Hişâm b. Hassân (ö. 1478/764-5), Abdullah b. Avn (ö. 151/768), Saîd b. Ebû Arûbe (ö. 156/773), Şu'be b. Haccâc (ö. 160/776), Hammâd b. Seleme, Hammâd b. Zeyd, Vüheyb b. Hâlid (ö. 165/781) ve Abdülvâris b. Saîd (ö. 180/796).

Ardından bu işlemin sağlamasını yapmak için 900 civarındaki râvi grubunun içerisinden tâbiîn tabakasından itibaren rastgele seçilen $49^{20}$ kişi-

18 Tablo yapılırken öncelikle gerektiğinde ilgili bilginin kaynağına ulaşabilmek adına Word'den istifade edilmiştir. Ancak sayfa sayısı arttıkça (toplamda 235 sayfa) programın aşırı yavaşladığı ve kullanımının zorlaştığı görülmüş, bu sebeple bütün veriler Excel’e kopyalanmıştır. Bu da takdir edileceği üzere ciddi bir zaman ve emek kaybına yol açmıștır. Kanaatimizce en doğru yol bilgilerin tamamının Word'de râvilere tahsis edilecek başlıklara girilmesi, ardından istatistiki sonuçlar elde edilebilecek verilerin (nisbe ve tarih bilgileri gibi) Excel'e de taşınması yönündedir.

19 Maden, Hicrî II. Asır Ehl-i Hadîs Halkaları, s. 21-50.

20 Liste içinde vefat tarihi bilinmeyen kişiler de bulunduğundan kullanım kolaylığ 1 amacıyla râviler yukarıda da belirtildiği üzere İbn Hacer’in tabaka sistemine göre sıralandı. 
nin hoca-talebe ilişkileri Yûsuf b. Abdurrahman el-Mizzînin (ö. 742/1341) Tehzîbü'l-Kemâl'inden kontrol edilmiş ve en fazla atıf alan Basralı âlimler sıralanıp üstteki liste ile karşılaştırılmıştır. Bu aşamada Tehzîbüll-Kemâl'deki bilgilerden hareketle Ebû Mûsâ el-Eşáâi, Matar b. Tahmân el-Verrâk (ö. 125/742 [?]), Yûnus b. Ubeyd (ö. 139/756), Dâvûd b. Ebû Hind (ö. 140/757 [?]), Süleyman b. Tarhân et-Teymî (ö. 143/761), Cerîr b. Hâzim (ö. 170/786) ve Abdullah b. Mübârek de (ö. 181/797) listeye eklenmiş ve böylece bir önceki aşamada tespit edilen isim sayısı yirmi üç iken, bu kontrolle sayı otuza ulaşmıştır.

Anlatılan işlemlerin sonucunda elde edilen otuz kişilik râvi kümesinin hoca-talebe ilişkilerini ayrıntısıyla tespit etmek için her birinin rivayetleri Ahmed b. Hanbel' in el-Müsned'inin ilk yirmi cildinde ve Basralı râvilere tahsis edilen XXXIII ve XXXIV. ciltlerinde taranıp her bir râvi için bir hocatalebe ağı şeması çıkarılmıştır. Bu şemalarda rivayet sayılarına bakılarak her bir râvinin yakın hocaları ve talebeleri tespit edilmiştir. ${ }^{21} \mathrm{Bu}$ işlem sonucunda Ebû Mûsâ el-Eşaraî, Humeyd b. Hilâl, Hâlid el-Hazzâ, Matar el-Verrâk, Ali b. Zeyd b. Cüdên, Dâvûd b. Ebû Hind, Süleyman et-Teymî, Saîd el-Cüreyrî, Avf el-A'râbî, İbn Avn, Vüheyb b. Hâlid ve Abdülvâris b. Saîd isnadlarda çok yaygın olarak görülmedikleri, yani haklarında yargıda bulunmaya imkân verecek rivayet malzemesi olmadığı için, Abdullah b. Mübârek ise coğrafi olarak daha ziyade Kûfe ile irtibatlı olduğu için devre dışı bırakılmıştır. Böylece ilgili küme on yedi kişiye düşürülmüştür.

İlgili aşamanın ardından gerek el-Mektebetü’ş-Şâmile ile yapılan bu taramada gerekse bizzat el-Müsned'in Basra ciltlerinin okunması esnasında diğer bazı isimlerin isnadlarda çokça geçtiği tespit edilmiştir. Bu taramalar neticesinde Hişâm ed-Destüvâî, Ma'mer b. Râş̧id (ö. 153/770), Hemmâm b. Yahyâ (ö. 164/780 [?]) ve İbn Uleyye (ö. 193/809)22 listeye eklenmiştir. Dolayısıyla araştırma kümesindeki râvi sayısı yirmi bir kişiye çıkmıştır. Ayrıca ilgili kümede

Buna göre II. (VIII.) asırda yaşamış râvilerin İbn Hacer'in sisteminde sekizinci tabakaya kadarki kısımda bulunduğu görüldü. Sahabe tabakası hariç her bir tabakadan rastgele yedişer kişi seçilerek mezkûr tarama gerçekleştirildi.

21 Yakın hoca-talebe ilişkilerini inşada kullanılan rivayet sayılarının burada açıkça zikredilmeme sebebi sadece rivayet sayılarından hareketle kesin yargılara gidilmemesi, sayıların zann-ı galip oluşturmak için kullanılması ve sonuçların görüleceği üzere pek çok aşamayla birtakım revizelere uğramış olmasıdır.

22 İsnadlarda ismine sıkça rastlanan ve İbn Uleyye ile aynı tarihte vefat eden Gunder'in (ö. 193/809) araştırma kümesine dahil edilmemesi bir sorun olarak görülebilir. Ancak çalışmada İbn Uleyye'ye hocası Eyyûb'dan dolayı ve Eyyûb ile ilişkisi bağlamında temas edilmişken ondan bir sonraki nesilde yer alan Şu'be’nin talebeleri II. (VIII.) asrın ikinci yarısına sarktığı için Şu'be ile sıkı mülazemeti bulunan Gunder kümeye eklenmemiştir. 
adı geçen bazı âlimlerin Basra dışındaki yakın hocaları ve talebeleri de bu aşamada belirlenmiştir. Buna göre Medine’den Ebû Hüreyre (ö. 58/678), Ebû Seleme b. Abdurrahman, Saîd b. Müseyyeb (ö. 94/713) ve Nâfi ile (ö. 117/735) Şam’dan Evzâînin Basralı muhaddislere kaynaklık ettiği görülmektedir.

Bütün bu ana kümeyi daraltma işlemlerinin sonucunda tâbiîn ulemasından Hasan el-Basrî, Muhammed b. Sîrîn, Sâbit el-Bünânî ve Yahyâ b. Ebû Kesîr'in halka sahibi muhaddisler olarak öne çıktıkları tespit edilmiştir. Zira bu isimler hem ilk kümeye dahil edilmelerini gerektirecek ölçüde rical kaynaklarında anılmışlardır hem de rivayet kaynaklarında kayıtlı binlerce Basra isnadında sıklıkla geçmektedirler. Yukarıda farklı işlemlerin ardından daraltılan râvi kümesindeki isimlerse bu dört merkezî şahsın hocaları, talebeleri ya da talebelerinin talebeleridir. Buna göre el-Müsned çerçevesindeki isnad verileri ile ortaya çıkan dört hadis halkası sırasıyla şöyledir:

1. Hasan el-Basrî (ö. 110/728) Halkası: Sadece isnad verileriyle yetinerek Hasan el-Basrînin yakın hocalarını tespit etmek mümkün değildir. Bunun sebebi Hasan’ın belli bir usulle elde etmediği yazılı kaynaklardan ve görüşmediği kimselerden rivayette bir sorun görmemesi ve bilgiyi sahibine isnat etmek konusundaki mütesahil tavrıdır. Ancak incelenen isnadlardan onun yakın talebelerinin Katâde b. Diâme ve Yûnus b. Ubeyd olduğu tespit edilebilmektedir. İsnad verilerine göre Katâde aynı zamanda Basra'da Enes'in, Medine'de Saîd b. Müseyyeb'in de yakın talebelerindendir. Hatta o, Enes'e nispetle ayrı bir halka sahibi olarak dahi zikredilebilir. ${ }^{23}$ Katâde’nin en yakın talebeleri ise Hişâm ed-Destüvâî, Saîd b. Ebû Arûbe, Şu'be b. Haccâc ve Hemmâm b. Yahyầdır.

2. Muhammed b. Sîrîn (ö. 110/729) Halkası: İsnad verilerine göre İbn Sîrîn'in en yakın hocası Medineli Ebû Hüreyre'dir. Onun bilgi birikimi İbn Sîrîn vasıtasıyla Basra'ya geçmiştir. İbn Sîrîn'in en yakın talebeleri ise Eyyûb es-Sahtiyânî ve Hişâm b. Hassân'dır. Bu iki isimden Eyyûb, aynı zamanda Medineli Nâf'in yakın talebelerindendir. İsnadlar Eyyûb'un yakın talebelerinin Ma'mer b. Râşid, Hammâd b. Zeyd ve İbn Uleyye olduğunu gösterir. Hişâm’n ise yakın talebesini tespit etmek kolay görünmemektedir.

3. Sâbit el-Bünânî (ö. 127/744) Halkası: İsnad verilerine göre Sâbit'in en yakın hocası Enes b. Mâlik, en yakın talebesi ise Hammâd b. Seleme'dir.

4. Yahyâ b. Ebû Kesîr (ö. 129/747) Halkası: İsnad verilerine göre Yahyầnın en yakın hocası Ebû Seleme b. Abdurrahman, en yakın talebeleri ise Hişâm ed-Destüvâî ve Şamlı Evzâî̉dir.

23 Enes b. Mâlik rivayetlerindeki öncelikli konumuna dair bk. Ebû Dâvûd, Suâlât (Âcurrî), s. 154; İbn Ebû Hâtim, el-Cerh ve't-ta'dîl, II, 376; VII, 182. 
Ahmed b. Hanbel'in el-Müsned'inden elde edilen bu sonuçların sağlaması Abdürrezzâk es-Sanânî ve İbn Ebû Şeybe’nin el-Musanneflerinin ilk üç cildi üzerinden yapılacaktır. ${ }^{24}$ el-Musanneflerin isnadlarına göre Hasan el-Basrî halkasında herhangi bir değişiklik olmazken -el-Müsned özelindeki taramada- İbn Sîrîn halkasında veri yetmezliğinden dışarıda bırakılan Abdullah b. Avn’nn, Eyyûb ve Hişâm'la birlikte İbn Sîrîn'in en yakın talebeleri arasına eklenmesi zorunluluğu ortaya çımıştır. Nitekim ileride isnad verilerinin sonuçları rical kaynaklarındaki bilgilerle kıyaslandığında bu ilavenin doğru olduğu görülecektir. ${ }^{25}$ Sâbit el-Bünânî halkasının talebe tabakası konusunda Abdürrezzâk'in el-Musannef indeki veriler el-Müsned'den farklı bir tablo ortaya çıkarmaktadır. el-Musannef teki isnad verilerine göre Sâbit’ten en çok nakilde bulunan kişi Ma'mer b. Râşid ise de ikili arasında sıkı bir hoca-talebe ilişkisi olabileceği öngörüsü rical kaynaklarınca desteklenmez. Abdürrezzâk’’n Basra rivayetlerine büyük oranda en yakın hocası Ma'mer üzerinden ulaştığı dikkate alındığında bu durum şaşırtıcı değildir. İbn Ebû Şeybe'nin el-Musannef inde ise el-Müsned'de olduğu gibi Enes Sâbit' in en yakın hocası, Hammâd b. Seleme en yakın talebesidir. Yahyâ b. Ebû Kesîr' in halkasında da durum Sâbit'inkiyle aynıdır. Abdürrezzâkın el-Musannef indeki verilere göre Yahyầnın en yakın hocası Ebû Seleme b. Abdurrahman, en yakın öğrencisi Ma'mer'dir. İbn Ebû Şeybe'nin el-Musannefine göre ise elMüsned'le uyumlu olarak Yahyânın en yakın hocası Ebû Seleme, en yakın talebeleri Hişâm ve Evzâîdir. ${ }^{26}$

Görüldüğü üzere isnad verileri hoca-talebe ilişkilerini tespitte büyük oranda işlevseldir. Ancak tek bir kaynaktan istifade etmek İbn Avn örneğinde görüldüğü gibi birtakım hatalı yargılara sebep olabilmektedir. Zira taramaya esas teşkil eden kitabın yazılış amacı, alanı ya da ilgili olduğu konular gibi hususların farklı sonuçlara sebep olabileceği dikkate alınarak bir ana

24 Tarama için fikhî bir tertibi benimseyen ilgili el-Musanneflerin ilk üç cildinin seçilmesi bu kısımlardaki rivayetlerin geneli itibariyle dönem ve coğrafyadan bağımsız olarak her bir müslümanın günlük yaşantısıyla ilgili olmasından kaynaklanır. Nitekim Abdürrezzâk’n ilgili ciltleri abdest, hayız, namaz, cuma namazı, bayram namazı, Kur'an’ın faziletleri ve cenâiz konularını içerirken İbn Ebû Şeybe’nin metninin ilk üç cildinde de abdest ve namaz konularına yer verilir. Tabii burada farklı coğrafyalardaki rivayet niteliğinin farklı olabileceği, yani özellikle tartışmalı fıkıh konularında belli rivayetlerin belli bölgelerde öne çıktığı düşünülebilir. Ancak bu sorunun en azından çalışmamız çerçevesinde cevaplanması mümkün değildir.

25 İbn Avn'in listeye el-Musannef ler sayesinde eklenmesi, onun merfû haberlerden ziyade tâbiîn fetvalarını nakletmekle ilgilenmesinin bir sonucudur. Bundan dolayı olsa gerek kendisinin Buhârînin el-Câmiu's-sahîh'indeki rivayetleri de azdır.

26 Çağdaş bir araştırmaya göre de Evzâînin Sünen'indeki rivayetlerin dörtte biri (\%24) Yahyẩdan gelir (Aydın, Hadis Metodolojisi Üzerine Düşünmek, s. 67-68). 
kaynaktan elde edilen tarama verilerinin birkaç kaynakla daha teyit edilmesi gerekmektedir. Öte yandan rical verilerine gidilmeden yalnızca isnadlar üzerinden net yargılar serdetmek de doğru olmayacaktır. Basralı tâbiînden Humeyd et-Tavîl bu duruma örnek verilebilir. Onun rivayetleri incelendiğinde en yakın hocası olarak Enes b. Mâlik, en yakın talebesi olarak da Hammâd b. Seleme ön plana çıkar. Rical kaynaklarına başvurulduğunda ise farklı bir tabloyla karşılaşılır. Zira rical kaynaklarına göre Humeyd, Enes’ten doğrudan sadece on sekiz yahut yirmi dört rivayet almış, ${ }^{27}$ geri kalan rivayetlerinin çoğuna Sâbit el-Bünânî üzerinden ulaşmış, ancak onu düşürerek Enes'ten nakilde bulunmuştur. Bu örneğin de gösterdiği üzere, tedlis ve irsal gibi tâbiîn döneminde çokça karşılaşılan durumları dikkate alarak rivayet verilerinin rical ve usul eserlerindeki bilgilerle karşılaştırılması gerekmektedir.

Rical verilerine geçmeden önce isnad taramasındaki birtakım zorluklara da temas edilmelidir. Bu işlemin en büyük dezavantajlarından biri araştırmacının aynı zamanda birden çok ihtimalle tarama yapmaya mecbur oluşudur. Bilindiği üzere râviler isnadlarda her zaman "Zeyd İbn Amr" kalıbıyla anılmak yerine "Zeyd" ve "İbn Amr" gibi kısaltmalarla ya da künyeleriyle de kayıtlıdırlar. Özellikle 100’lere (720) kadar rivayet eyleminin hayatın doğal akışı içerisinde gerçekleşmiş olması bu gibi kullanımların en temel sebebi gibidir. Bu sebeple Muhammed b. Sîrîn'in rivayet ilişkilerine dair bir tarama yaparken Muhammed b. Sîrîn, Muhammed, İbn Sîrîn ve nadiren de olsa künyesi olan Ebû Bekir de tarama ifadeleri arasına eklenmelidir. ${ }^{28} \mathrm{Bu}$ tarz bir taramanın ardından araştırmacının karşılaşacağı binlerce verinin doğru bir şekilde okunup fişlenmesinin gerekliliği ise ayrı bir problemdir. Mesela sadece "Muhammed" ifadesiyle yapılacak bir taramanın ne kadar yüksek sayıda bir sonuç vereceği açıktır. Bundan dolayı sonuçları doğru değerlendirebilmek için kişide tarama öncesi İbn Sîrîn'in hoca-talebe ilişkilerine dair bir ön bilginin bulunması gerekmektedir. Bu da rivayet metinleriyle rical metinlerinin birlikte değerlendirilme mecburiyetini ve bu iki kaynağın iç içeliğini gösteren bir diğer noktadır.

Tarama öncesi rical kaynaklarından elde edilen hoca-talebe ilişkilerinin bu aşamada doğru tespiti ve değerlendirilebilmesi her zaman mümkün olmayabilir. Nitekim aynı dönemde, aynı bölgede yaşamış ve benzer kişilerden rivayette bulunmuş Hammâd b. Zeyd ve Hammâd b. Seleme'nin durumları buna örnek verilebilir. İsnadlarda mutlak olarak "Hammâd" geçtiğinde bu-

27 Sirasıyla bk. İbn Hibbân, es-Sikāt, IV, 148; Yahyâ b. Maîn, et-Târîh (Dûrî), IV, 318; İclî, Ma'rifetüss-sikät, I, 325.

28 Künyenin cümlede farklı konumlarda bulunabileceği dikkate alınarak "Ebû ..." ifadesinin yanı sıra "Ebâ ..." ve "Ebî ..." kullanımları da taramaya eklenmelidir. 
nun İbn Zeyd mi yoksa İbn Seleme mi olduğunu tespit etmek her zaman mümkün değildir. Bu konuyu gündeme getiren usul âlimlerinin açıklamaları da meseleyi tam mânasıly çözüme kavuşturmaz. ${ }^{29} \mathrm{Bu}$ tarz zorluklar hocatalebe ilişkilerini tespite engel teşkil etmese de kullanılacak verinin sayısında birtakım tutarsızlıklara sebep olabilmektedir.

\section{B) Rical Verileri}

Erken dönem rical kaynaklarında halka tespitinde kullanılabilecek çok sayıda bilgi dağınık da olsa yer alır. Özellikle Yahyâ b. Maîn, Ali b. Medînî ve Ahmed b. Hanbel gibi incelenen döneme yakın müelliflerin ilel ve ricale dair eserleri Basra ehl-i hadisi açısından zengin bilgiler ihtiva eder. Erken dönem ilel ve cerh-ta'dil otoriteleri olan bu âlimlerin Hz. Peygamber'e atfedilen bilginin güvenilir olanını olmayanından ayırmak için büyük oranda "bir hocanın rivayetlerinde hangi talebenin tercih edileceği, en güvenilir talebelerin kimler olduğu ve varsa tespit edilen hatanın kimden kaynaklandığı" gibi soruları merkeze alarak derledikleri bu bilgiler halkaların inşasında kullanılmaya müsaittir. ${ }^{30}$ Rical kaynaklarındaki veriler "doğrudan yakın hoca-talebe ilişkisini ve halka devamlılığını gösteren bilgiler" (aslî veriler) ve "doğrudan olmasa da diğer bilgilerle birlikte değerlendirildiğinde buna işaret eden bilgiler" (tâli veriler) olarak iki başlıkta incelenebilir. Mezkûr bilgilerin tek başına her zaman doğru sonuç vermeyeceği ve çalışma boyunca değinilen diğer bilgi türleriyle bir arada düşünülmesi gerektiği yeniden hatırlatılmalıdır.

\section{Aslî Veriler}

Rical kaynakları ayrıntılı bir şekilde incelendiğinde halka tespitine imkân sağlayan çok miktarda farklı bilgiyle karşılaşılır. Nitekim 1. Hoca-talebe ilişkisinin, bir talebenin hocadan sonra onun yerini alması sonucunu doğurmas1, 2. Hoca ile talebe arasındaki ilişkinin süresi ve mahiyeti, 3. Herhangi bir talebenin bir hocadan ileri düzeyde istifade ettiğini bizzat söylemesi, 4. Rical kaynaklarında hoca-talebe ilişkisine delalet eden kavram ve lafızların kullanılması ve 5. Sonraki âlimlerin bir hocanın talebeleri arasında hiyerarşik değerlendirmeler yapması gibi unsurların pek çok örneğine rical kaynaklarında rastlanmaktadır. Önemli olan husus bu bilgileri makul ve anlaşılabilir bir anlam çerçevesine oturtabilmektir.

$29 \mathrm{Bu}$ konuda geniş bir tetkik için bk. Süyûtî, Tedrîbürr-râvî, V, 443-47.

30 Konuya dair dağınık malzeme İbn Receb’in (ö. 795/1393) Şerhu İleli’t-Tirmizîsinde (II, 472-551) bir arada görülebilir. 
$\mathrm{Bu}$ tarz bilgilerin ilki, kaynaklarda çok fazla yer almayan ancak halkanın bir başkası tarafından devam ettirildiğini açıcça belirten ifadelerdir. Nitekim Humeyd b. Hilâl ile (ö. 120/737 civarı) Süleyman b. Mugīre (ö. 165/781) arasında geçen bir diyalogda Hasan el-Basrînnin yerine yakın talebesi Yûnus b. Ubeyd'in ve Muhammed b. Sîrîn'in yerine yakın talebesi Eyyûb es-Sahtiyânînin geçeceğinin belirtilmesi bunun bir örneğidir. ${ }^{31}$ İbn Avn’n "İbn Sîrîn vefat edince Eyyûb’a gitmeye karar verdik"32 sözü bu tahminin İbn Sîrîn kısmının doğru çıktığını gösterir. Bu sonucun ortaya çıkmasında Eyyûb’un İbn Sîrîn'in diğer yakın talebesi Hişâm'a kıyasla ilmî bakımdan daha yetkin oluşu da etkilidir. Hasan’n halkasının âkıbetiyle ilgili diğer bir bilgi de kaynaklarda yer alır: Mansûr b. Zâzân’a (ö. 129/746) göre kendisinin de içinde bulunduğu bir grup Hasanı̀n ardından halkanın başına Ali b. Zeyd b. Cüd'ânı̀n geçmesini istemişlerdir. ${ }^{33}$ Ancak Ahmed b. Hanbel'in verdiği bilgiye göre Hasan’n vefatından sonra halkanın başına yakın talebesi Katâde b. Diâme geçmiş ve vefatına kadar halkanın başında kalmıştır. Onu sırasıyla Matar b. Tahmân el-Verrâk ve Saîd b. Ebû Arûbe izlemiştir. ${ }^{34}$ Dolayısıyla Humeyd, Süleyman ve Mansûr'un öngörüleri isabetli olmamıştır. Bu sonucun en muhtemel sebebi Katâde ve Eyyûb’un, hocaları Hasan ve İbn Sîrîn'le yetinmeyip gerek şehir içerisinde gerekse diğer şehirlerde başka kişilere de yakın talebelik yapmış olmalarıdır. Zira Katâde, Hasan dışında Enes b. Mâlik'ten çokça istifade ederken Eyyûb Medineli Nâfíin yakın talebeleri arasında sayılmıştır. Halbuki Yûnus b. Ubeyd'in yalnız Hasan’la, Hişâm b. Hassân’ın ise sadece İbn Sîrîn'le sıkı ilişkisi vardır. ${ }^{35}$ Rivayet verilerinde ön plana çıkmayan ve rical kaynaklarından elde edilen verilere göre Hasan'la ilişkisi Yûnus ve Katâde kadar olmayan Ali b. Zeyd ise hadis rivayetinde birçok kimse tarafından eleştirilmiştir. ${ }^{36}$

Hoca-talebe arasındaki yakınlı̆̆ gösteren bir diğer bilgi grubu, râvinin hocasıyla geçirdiği uzun zamana vurgu yaptığı ifadelerdir. Sâbit el-Bünânînin hocası Enes b. Mâlik'le kırk sene geçirdiğine dair kaynaklarda yer alan ve-

31 İbn Sa'd, et-Tabakāt, IX, 248.

32 İbn Sa'd, et-Tabakāt, IX, 249.

33 Zehebî, A 'lâmün-nübelâ', IX, 240. Ali b. Zeyd'i halkanın başında görmek isteyenlerin bu isteklerini nasıl gerekçelendirdikleri bilinmemektedir. Ancak Ali b. Zeyd'in, Hasan’nn vefatı sonrasında onun yerini alamayınca kendi halkasını kurduğu düşünülebilir. Hammâd, Ali’nin "meclisine ancak seçkin kişileri aldığı"ndan bahsederken (İbn Ebî Hâtim, el-Cerh, VI, 186) onun bu halkasına işaret ediyor olsa gerektir.

34 Ebû Züra, Târîh, s. 121. Watt da Katâde’nin Hasan’ın halkasının başına geçtiğine işaret eder (İslâm Düşüncesinin Teşekkül Devri, s. 152).

35 Maden, Hicrî II. Asır Ehl-i Hadîs Halkaları, s. 89 (Yûnus), 65 (Hişâm).

36 İbn Hacer, Tehzîb, IV, 194-96. 
riler ${ }^{37}$ ikili arasındaki sıkı ilişkinin bir göstergesidir. Aynı şekilde Katâde b. Diâme’nin “Hasan’n derslerine on iki sene devam ettim. Üç sene sabah namazını birlikte kıldık. Düşünsene! Benim gibi biri onun gibi birinden ders aldı" (mislî ehaze 'an mislihî) ${ }^{38}$ sözleri ikili arasındaki hoca-talebe ilişkisini açıç̧a gösterir. Hammâd b. Zeyd'in, hocası Eyyûb'la yirmi sene birlikte bulunduğuna dair bilgiler de bu bağlamda zikredilebilir. ${ }^{39}$

Nadir olmakla birlikte kimi râvilerin belirli bir hoca ile uzun zaman geçirdiğine yönelik ifadelerinin yakın hocalık-talebelik anlamına gelmediği durumlar da vardır. Nitekim Hişâm b. Hassân’ın Hasan el-Basrî ile on senelik birlikteliğine dair iddiası ${ }^{40}$ Hasan’ın diğer talebeleri Eşas b. Abdülmelik (ö. 142/759 [?]), ${ }^{41}$ Amr b. Ubeyd (ö. 144/761), ${ }^{42}$ Abbâd b. Mansûr (ö. 152/769) ve Cerîr b. Hâzim ${ }^{43}$ tarafından şiddetle reddedilmiştir. ${ }^{44}$ İsnad verilerine göre de mezkûr birliktelik rivayete çok fazla yansımamıştır. Bu da rical kaynaklarındaki bilgilerin bir araya getirilerek ve isnad verileriyle sağlaması yapılarak değerlendirilmesi gerektiğini göstermektedir.

Halkaların tespitinde kullanılacak bir diğer veri talebenin hocasının bilgi birikimini elde ettiğini açıcça belirtmesidir. Eyyûb es-Sahtiyânînin "Muhammed (b. Sîrîn)'in kendisinden işitmediğim bir hadisini bir başkasından işitmek bana ağır gelirdi” sözünü duyan Ma 'mer b. Râşid'in, "Eyyûb’un kendisinden işitmediğim bir hadisini bir başkasından işitmek de bana ağır gelir" demesi konuya verilecek örneklerden biridir. Diğerlerinde olduğu gibi bu tarz bilgiler de kaynaklardaki ilgili bilgilerle kontrollü olarak kullanılmalıdır.

Yine çok örneği olmasa da bazı râviler hocalarıyla kısa bir zaman geçirmelerine rağmen onların bilgi birikimini elde etmiş ve mezkûr hocanın yakın talebeleri içerisinde değerlendirilmişlerdir. Üst düzey ezberleme kabiliyetiyle öne çıkan Katâde’nin Medineli Saîd b. Müseyyeb ile ilişkisi buna örnek verilebilir. Zira rivayetlere göre Katâde, İbnü'l-Müseyyeb’in yanında sadece sekiz

37 Buhârî, et-Târîhu'l-kebîr, II, 160.

38 İbn Sa'd, et-Tabakāt, IX, 228; Fesevî, el-Ma'rife, II, 279.

39 Yahyâ b. Maîn, et-Târîh (Dûrî), IV, 214.

40 Yahyâ b. Maîn, et-Târîh (Dûrî), IV, 219; a.mlf., Ma'rifetürr-ricâl, I, 168; Ahmed b. Hanbel, el-İlel, II, 38; Buhârî, et-Târîhu'l-kebîr, VIII, 197.

41 Ahmed b. Hanbel, Min Kelâmi'l-İmâm Ebî Abdillâh Ahmed b. Hanbel (Meymûnî), s. 177;

İbn Adî, el-Kâmil, VIII, 417.

42 Mizzî, Tehzîbü’l-Kemâl, XXX, 193.

43 İbn Adî, el-Kâmil, VIII, 416.

44 Hişam’ın Hasan’ın yakın talebelerinden olup olmadığı tartışması için bk. Maden, Hicrî

II. Asır Ehl-i Hadîs Halkaları, s. 92-93.

45 İbn Sa'd, et-Tabakāt, IX, 250. 
gün ${ }^{46}$ kalmışsa da hocasının bütün ilmî birikimini almıştır. Birlikteliklerinin üçüncü gününde Katâde’ye, "Artık gidebilirsin, bende ne var ne yok hepsini aldın!" 47 diyen Saîd, daha sonra Katâde’yi, "Bana Katâde’den daha hâfız bir Iraklı gelmedi”" ${ }^{8}$ diyerek övmüştür. Ancak menkıbevi yönü ağır basan bu rivayetteki gibi durumlarla sık karşılaşılmadığının altı çizilmelidir.

Halkaların tespitinde başvurulacak diğer bir veri sâhib-ashâb-sahibe, celîs-celese ilâ-mücâlese, ihtelefe ilâ, erva'n-nâs, evsaku'nâs, ahfazu'n-nâs, a'lemün-nâs, esbetün-nâs ve esnedü’n-nâs gibi yakın hoca-talebe ilişkisine açıkça işaret eden kavramlardır. Bu kullanımların bir kısmının hoca kaydıyla düşünülmesi gerektiği de açıktır. Klasik metinler okunurken kelime anla$\mathrm{m}$ verilerek geçilen bu gibi ifadelerin her birinin halka verileri ile birlikte okunduğu takdirde aslında birer kavram olduğu ve göründüğünden çok daha fazla anlam ifade ettiği rahatlıkla anlaşılmaktadır. İsm-i tafdil kalıbında olan bu tür kullanımlar çoğu zaman doğru sonuç vermektedir. Söz gelimi İbn Sîrîn'in hadislerini en iyi ezberleyen kimsenin (ahfaz) Hişâm b. Hassân ${ }^{49}$ ve en iyi bilenin ( $\left.a^{c} l e m\right)$ Eyyûb ${ }^{50}$ olduğu, Hammâd b. Selemènin Sâbit'in en sağlam (esbet) talebesi olduğu ${ }^{51}$ ve Yahyâ b. Ebû Kesîr'in hadislerini en iyi bilen kimselerin Hişâm ed-Destüvâî (esbet fî Yahyâ) ${ }^{52}$ ve Evzâî (a lâ ashâbi Yahyâ $)^{53}$ olduğu ifade edilmiştir ki bu ifadeler isnad verileriyle elde edilen sonuçları destekler. Çoğu zaman bir hocanın yakın talebesi anlamına gelen sâhib/ashâb ifadesi kişinin herhangi bir talebesini ve/veya akranı/dostunu, hocasını ve kimi zaman da hadis ilmi ile doğrudan ilgili olmamakla birlikte bir aileye yahut mesleğe aidiyeti ifade etmek için de kullanılır. ${ }^{54}$ İbn Sîrîn'in Ebû Hüreyre'nin altı kişilik yakın talebe grubu (ashâb $)^{55}$ ve Yûnus b. Ubeyd'in Hasan’n yakın talebeleri arasında zikredilmesi ${ }^{56}$ kavramın yakın

46 İbn Sa'd, et-Tabakāt, IX, 229.

47 Buhârî, et-Târîhu'l-kebîr, VII, 186.

48 İbn Ebû Hâtim, el-Cerh ve't-ta'dîl, VII, 181.

49 Yahyâ b. Maîn, et-Târîh (Dûrî), IV, 219; İbn Ebû Hâtim, el-Cerh ve’t-ta'dîl, IX, 54 .

50 İbn Adî, el-Kâmil, I, 143.

51 Ahmed b. Hanbel, el-i̇lel, II, 131; III, 268; a.mlf., Suâlât (Ebû Dâvûd), s. 148; Yahyâ b. Maîn, et-Târîh (Dûrî), IV, 265, 297; Fesevî, el-Ma'rife, II, 166.

52 Ahmed b. Hanbel, Suâlât (Ebû Dâvûd), s. 144; İbn Ebû Hâtim, el-Cerh ve’t-ta'dîl, IX, 76-77.

53 Yahyâ b. Maîn, et-Târîh (Dûrî), IV, 180, 457-58; a.mlf., Ma'rifetürr-ricâl, II, 195; Ebû Dâvûd, Suâlât (Âcurrî), s. 168.

54 Sâhib/ashâb kavramının bazı kullanımları için bk. Topgül, İsnâdın Satır Araları, s. 9697, 116-24. Sâhib kavramının yakın talebe anlamında kullanıldığı bir örnek için bk. Makdisi, Ortaçağda Yüksek Öğretim, s. 200-202.

55 Ali b. Medînî, Suâlât (İbn Ebî Şeybe), s. 81.

56 İbn Ebû Hâtim, el-Cerh ve't-ta'dîl, IX, 298. 
hoca-talebe ilişkisine işaret eden örneklerinden sadece birkaçıdır. Bu tarz bir mahiyet arzetmeyen kullanımlara ise Sâlih b. Ebû Meryem ${ }^{57}$ ve zayıf bir râvi olan Hakem b. Abdülmelik ${ }^{58}$ hakkında kullanılan "sâhibü Katâde" ifadeleri örnek olarak verilebilir. Zikri geçen kişiler hakkındaki bilgiler incelendiğinde Sâlih'in Katâde’nin hocası, Hakem'in ise sıradan bir talebesi olduğu görülür. Dolayısıyla sâhibu/ashâbu fulân tarzı ifadelerin anlamının doğru tespiti önemlidir. Zira kaynaklarda sadece bir hocanın bir ya da birkaç rivayetiyle tanınan, yani çok fazla bilinmeyen bazı kimselerin, o hocanın sâhibi olarak anıldığı örneklere rastlanır. Bu noktada, halka inşasında sadece rical verileri ile yetinilmeyip isnad verilerinin de aktif bir şekilde kullanılması ve böylece yanlış bazı anlamaların önüne geçilebileceği bir defa daha hatırlatılmalıdır.

Halkaların tespitinde kullanılacak bir diğer veri grubu ise sonraki hadis münekkitlerinin bir hocanın talebeleri arasındaki ilmî öncelik ve sonral1ğı gösteren Fülân ehabbu ileyye min fülân fî hadîsi fülan/fî fülân tarzı nisbî cerh-ta'dil ifadeleridir. ${ }^{59}$ Mesela talebelerinin Yahyâ b. Maîne yönelttikleri bazı sorular yakın hoca-talebe ilişkisinin nisbî cerh-ta'dil ifadeleri üzerinden takip edilebileceğini gösterir. Nitekim Dârimînnin İbnü’l-Müseyyeb’in hadisinde Zührî̀yi mi Katâde’yi mi tercih edeceği sorusuna Yahyâ "ikisini de" diye cevap vererek bir ayırım yapmaz. ${ }^{60}$ Bir başka seferinde Eyyûb’un rivayetinde Hammâd b. Zeyd'i mi yoksa İbn Uleyye’yi mi tercih edeceği sorusunu ise "Hammâd" diye cevaplar. ${ }^{61}$ Sorulara dikkat edildiğinde genelde hocanın yakın talebeleri arasında bir karşılaştırmanın yapıldığ tarz ifadelerin hoca-talebe ilişkisine delaletine hükmedileceği zaman diğer veriler dikkate alınmalıdır. Hasan el-Basrînnin hadisinde Yûnus b. Ubeyd'i mi Humeyd et-Tavîl'i mi tercih ettiği sorusu üzerine Yahyẩnın sessiz kalması bu duruma örnek verilebilir. Zira Humeyd, Hasan’n talebeleri arasında zikredilse de Yûnus'la kıyaslanacak bir önceliğe sahip değildir. Bu tarz bir kıyaslamada -halka şeması dikkate alınarak- Yûnus'un Katâde ile kıyaslanması beklenirdi. Dolayısıyla sadece bu örnekten hareketle Humeyd'in Hasan'ın yakın talebelerinden olduğu iddia edilemez. Ayrıca rivayetin devamında hocasının bu tavrını nakleden Dârimînin Yûnus'u net bir şekilde tercih etmesi onun Hasan’n rivayetlerinde Yûnus ve Humeyd arasındaki önceliğin-sonralığın farkında olduğunu gösterir. ${ }^{62}$ Zikredilen örnekler halka tespitinde kullanı-

57 Yahyâ b. Maîn, et-Târîh (Dûrî), IV, 131.

58 Yahyâ b. Maîn, Suâlât (İbnü'l-Cüneyd), s. 158.

59 Âşıkkutlu, "Bir İsnad Tenkid Yöntemi Olarak Şartlı Cerh-Ta'diller”, s. 49-80.

6o Yahyâ b. Maîn, Târîh (Dârimî), s. 44.

61 Yahyâ b. Maîn, Târîh (Dârimî), s. 54 .

62 Yahyâ b. Maîn, Târîh (Dârimî), s. 100-101, 234. 
labilecek nisbî cerh-tadil bilgilerinin halkaların varlığının tespiti ile daha anlamlı hale gelebileceğini de göstermektedir. ${ }^{63}$ Ayrıca hem Zeyd ve Amr’’n, hocaları Muhammed'in bilgi birikimini aktarmadaki konumlarına dair verilen bilgilerin hem de Zeyd ve Amr'ın, hocaları Muhammed zikredilmeksizin kıyaslandığı durumların doğru bir şekilde anlaşlabilmesi ancak halkaların tespitine, yani ilgili kişiler arasındaki irtibatların bilinmesine bağlıdır.

\section{Tâli Veriler}

Halka tespitinde başvurulacak diğer bir bilgi grubu "tâli" yahut "ikincil veriler" olarak isimlendirilebilecek, hoca-talebe arasında daha çok şahsî ilişkileri gösteren bilgilerdir. Rical kitaplarında sıkça yer alan bu bilgilerin geneli, halka yapıları ve ikili irtibatlar dikkate alınmadan okunduğunda çok fazla bir şey ifade etmez. Halka yapıları dikkate alındığında ise bu tür veriler hem daha anlamlı hale gelmekte hem de isnad verileri ile aslî rical verilerinin sağlamasını yapma imkânı vermektedir.

Farklı türleri bulunan tâli verilerin başında talebenin hocasının doğum ve vefat tarihlerine dair verdiği bilgiler gelir. Hammâd b. Zeyd'in (ö. 179/795) hocası Eyyûb'un doğum ve vefat, ${ }^{64}$ Katâde'nin Basralı hocası Enes' in ${ }^{65}$ vefat ve Medineli hocası Saîd b. Müseyyeb'in ${ }^{66}$ doğum ve vefat tarihlerine dair verdiği bilgiler buna örnek olarak zikredilebilir.

Talebenin hocasının fizikî ve karakter yapısına dair verdiği bilgiler de halka tespitinde aktif olarak kullanılabilecek tâli verilerdendir. Hammâd b. Zeyd'in Eyyûb'un saç şekline, kullandığ 1 kınaya, ${ }^{67}$ giyim kuşamına ${ }^{68}$ ve kişiliğine, ${ }^{69}$ Yûnus b. Ubeyd'in hocası Hasan’ın hüzünlü tabiatına ${ }^{70}$ ve diğer bazı şahsî özelliklerine, ${ }^{71}$ Katâde’nin hocası Hasan’ın saç tıraşı periyoduna ${ }^{72}$ ve İbn Uleyye’nin hocası Yûnus b. Ubeyd'in kullandığ kınaya ${ }^{73}$ dair ifadeleri bu bağlamda zikredilebilir.

63 Doğrudan bu konuyla ilgili yakın zamanda neşredilen bir çalışmada ise mesele bu bakış açısıyla incelenmemiştir (Sarmini, "el-Mufâdale beyne'r-ruvât", s. 367-84).

64 Ahmed b. Hanbel, el-İlel, II, 326; Buhârî, et-Târîhu'l-kebîr, VIII, 402.

65 Yahyâ b. Maîn, Suâlât (Osmân b. Tâlût), s. 82.

66 Yahyâ b. Maîn, Suâlât (Osmân b. Tâlût), s. 81, 83 .

67 İbn Sa'd, et-Tabakāt, IX, 247.

68 Ahmed b. Hanbel, el-ìlel, I, 338, 406.

69 İbn Sa'd, et-Tabakāt, IX, 248, 249.

70 İbn Sa'd, et-Tabakāt, IX, 163.

71 Hasan’ın saç-sakaldaki beyaz kılların koparılmasını hoş görmemesi buna örnek olarak zikredilebilir (Ahmed b. Hanbel, el-İlel, I, 540).

72 İbn Sa'd, et-Tabakāt, IX, 142-43.

73 Ahmed b. Hanbel, el-ìlel, II, 388. 
Ayrıca talebenin ders halkasında gerçekleşen bazı olaylara ve hocasına sorulan sorulara, ${ }^{74}$ hocasının ibadetlerdeki tavrına dair bilgiler vermesi, ${ }^{75}$ hocasının naaşını yıkaması,${ }^{76}$ hocasının bazı ibadet alışkanlıklarını sürdürmesi, ${ }^{77}$ hocasının özel isteklerini yerine getirmesi, ${ }^{78}$ hocasına benzetilmesi, ${ }^{79}$ hocası tarafından övgüyle anılması, ${ }^{80}$ derse gelmediği zaman hocası tarafından sorulması, ${ }^{81}$ hocanın talebesine künye vermesi ${ }^{82}$ yolculuğa çıkarken hocası tarafından uğurlanması, hocasının kendisi için yol azığı hazırlaması ve gideceği yerdeki tanınmış hocalara yönlendirmesi ${ }^{83}$ yakın hoca-talebe ilişkisinin belirlenmesinde ve böylece halka tespitinde kullanılacak bilgilere örnek verilebilir. Rical kitaplarında yer alan ve ilk okunduğunda önemsiz ayrıntılar olarak görülen bu bilgilerin yukarıda değinilen aslî rical

74 Hammâd b. Zeyd'in Eyyûb'un halkasında gerçekleşen olaylara dair verdiği bilgiler için bk. Yahyâ b. Maîn, et-Târîh (Dûrî), IV, 183; Ahmed b. Hanbel, el-ïlel, I, 261, 406, 407, 494.

75 İbn Uleyye'nin, hocası Eyyûb'un teravih namazının aralarında talebelerine nafile namaz kıldırdığını (Ahmed b. Hanbel, el-ìlel, I, 496) ve ne Eyyûb’un ne de diğer hocası Yûnus b. Ubeyd'in kunutta ellerini kaldırdığını (Ahmed b. Hanbel, el-İlel, III, 176) belirtmesi ve Hammâd b. Seleme’nin hocası Sâbit'in gece namazına (İbn Sa'd, et-Tabakāt, IX, 232) ve Kadir gecesindeki tutumlarına dair verdiği bilgiler (İbn Sa'd, et-Tabakāt, IX, 231) örnek olarak anılabilir.

76 Eyyûb ve İbn Avn’n, hocaları İbn Sîrîn'in naaşını yıkamaları buna örnek olarak verilebilir (İbn Sa'd, et-Tabakāt, IX, 205). Ancak bu tarz bilgiler her zaman yakın hoca-talebe ilişkisini göstermeyebilir. Zira Eyyûb ve Humeyd et-Tavîl Hasan’n, yine Humeyd Sâbit'in cenazesini yıkamıştır (sırasıyla bk. İbn Sa'd, et-Tabakāt, IX, 177-78, 232).

77 Sâbit el-Bünânî, hocası İbn Ebû Leylânın (ö. 83/702) sabah namazını kıldıktan sonra güneş doğuncaya kadar Kur’an okuduğunu söyleyip kendisi de bunu uygulamış, Sâbit’ten sonra da talebesi Hammâd b. Seleme aynı faaliyeti sürdürmüştür (İbn Sa'd, et-Tabakāt, VIII, 231). İbn Sîrîn'in yakın talebeleri de hocalarının kına uygulamasını devam ettirmişlerdir (Ahmed b. Hanbel, el-ỉlel, II, 388). Bir başka örnekte Hammâd b. Zeyd ölü yıkamayla ilgili bilgileri hocası Eyyûb vasıtasıyla öğrenmiş ve bunu talebelerinden Süleyman b. Harb’e öğretmiştir (Yahyâ b. Maîn, et-Târîh [Dûrî], IV, 221-22).

78 Yûnus b. Ubeyd hocası Hasan'a elbise almak için çarşıya gitmiştir (Fesevî, el-Ma'rife, II, $50)$.

79 Hammâd b. Seleme’nin, “İbn Uleyye’nin hal harekâtını [şemâil] Yûnus b. Ubeyd’e benzetirdik" sözü buna örnek olarak verilebilir (Ahmed b. Hanbel, el-ìlel, II, 57-58, 365).

8o Eyyûb’un (İbn Ebû Hâtim, el-Cerh ve't-ta'dîl, II, 184) ve Hişâm b. Hassân’n (İbn Ebû Hâtim, el-Cerh ve't-ta'dîl, IX, 70) İbn Sîrîn tarafından, Katâde’nin İbnü'l-Müseyyeb tarafından övülmesi (İbn Ebû Hâtim, el-Cerh ve't-ta'dîl, VII, 181) buna örnek olarak gösterilebilir.

81 Sâbit'i "Hayrın anahtarları vardır. Sâbit de hayrın anahtarlarındandır" (Ahmed b. Hanbel, el-ìlel, II, 434; Buhârî, et-Târîhu'l-kebîr, II, 159) diye öven hocası Enes b. Mâlik, Humeyd et-Tavîl'in naklettiğine göre yanlarında Sâbit olmadığında talebelerine Sâbit’i sorar ve onu övgüyle anardı (İbn Sa'd, et-Tabakāt, IX, 231).

82 İbn Sîrîn'in talebesi Hişâm'a çocuğu olmamasına rağmen Ebû Abdullah künyesini vermesi (Buhârî, et-Târîhu’l-kebîr, VIII, 197) burada zikredilebilir.

83 Eyyûb’un, Mekke’ye giden öğrencisi Ma'mer için yaptıkları hakkında bk. İbn Sa'd, etTabakāt, VIII, 105; Buhârî, et-Târîhu’l-kebîr, V, 123. 
bilgileri ve isnad verileriyle birlikte değerlendirilmesi hem halkaların tespiti açısından önemlidir hem de rical kaynaklarındaki bilgilerin daha etkin bir şekilde kullanılmasına imkân verecektir.

\section{C) Tematik Veriler}

Halka tespitinde tematik yaklaşımın da hayli aydınlatıcı olacağı ileri sürülebilir. Mesela hadisle ilgili belli bir konu etrafındaki görüşleri birbiriyle aynı olan isimlerin, aslında ortak tavırlar sergileyen bir halkanın müntesipleri olabileceğini ileri sürmek teorik olarak mümkündür. Bununla birlikte ilgili konuda belli bir şehirdeki âlimlerin görüşlerinin olası bir ittifakı, ancak rical kaynaklarından ve isnad verilerinden elde edilen yargılarla örtüştüğünde anlamlı olacaktır. Yani tek başına tematik verilere dayanmak her zaman doğru sonuçlar vermeyebilir. İncelenen konu hakkındaki ortak görüş sahipleri hadis usulü kaynaklarında bir arada verilebildiği gibi daha başka klasik kaynaklarda dağınık olarak da yer alabilmektedir. Mesela hadis ulemasının geneli manen hadis rivayetini tecviz ederken, bazı muhaddisler manen rivayete karşı çıkarlar. Klasik literatür tetkik edildiğinde Basralı âlimlerin isimlerinin de kabul ve ret saflarında anıldığg görülür. Manen rivayete karşı çıktığ 1 bildirilen isimlerden biri, Basra hadis halkalarından birinin başında yer alan İbn Sîrîn'dir. ${ }^{84}$ İbn Sîrîn'in bu konudaki tavrını talebeleri Hişâm b. Hassân, ${ }^{85}$ Eyyûb es-Sahtiyânî, Abdullah b. Avn ${ }^{86}$ ve halkanın bir sonraki tabakasından İbn Uleyye ${ }^{87}$ sürdürmektedir. Sonuç olarak söz konusu tablo Basra ehl-i hadisinin İbn Sîrîn kolunda manen rivayet olgusunun hoş görülmediğini söylemeye imkân verir.

Burada örnek olarak zikredilecek ikinci mesele kitâbetül-hadîs tartışmalarıdır. I. (VII.) asrın sonlarında tartışılmaya başlanan ve muhtemelen II. (VIII.) asrın ikinci yarısı ile birlikte gitgide gündemden düşen kitâbetü’lhadîsi kimi âlimler uygun görüp teşvik etmiş, kimileri ise buna karşı çıkmışlardır. Bu iki zıt kutbun yanında sadece ezberleyinceye kadar bilgiyi kayıt altına almaya cevaz veren âlimler de vardır. Usul ve rical kaynaklarında bu konuda görüş bildiren muhaddislere bakıldığında aynı halkaya mensup muhaddislerin benzer tavırda oldukları görülür. Nitekim kronolojik bir seyir takip edilecek olursa İbn Sîrîn, ${ }^{88}$ Hişâm b. Hassân, ${ }^{89}$ Eyyûb

84 Ahmed b. Hanbel, el-ìlel, II, 266, 391; III, 198.

85 İbn Ebû Hâtim, el-Cerh ve't-ta dîll, IX, 71.

86 Ahmed b. Hanbel, Suâlât (Ebû Dâvûd), s. 143.

87 Hatîb el-Bağdâdî, el-Kifâye, II, 16.

88 İbn Sa'd, et-Tabakāt, IX, 193; Ahmed b. Hanbel, el-İlel, I, 245; II, 392.

89 İbn Adî, el-Kâmil, I, 97; Mizzî, Tehzîbü'l-Kemâl, XXX, 185. 
es-Sahtiyânî, ${ }^{90}$ Hâlid el-Hazzâ, İbn Avn, Vüheyb b. Hâlid, ${ }^{91}$ Abdülvâris b. Saîd ${ }^{92}$ ve İbn Uleyye ${ }^{93}$ hadis yazımını hoş görmeyen âlimler arasında zikredilir. ${ }^{94}$ İsnad verileri ve rical metinleri dikkate alınınca Eyyûb ile İbn Avnı̀n İbn Sîrîn ile sıkı irtibatları bilinmektedir. Hem İbn Sîrîn'den hem de yazımı hoş gören Ebû Kılâbe'den (ö. 104/722) ${ }^{95}$ istifade eden Hâlid el-Hazzâ, burada daha az yararlandığı İbn Sîrîn'den etkilenmiş gibidir. Abdülvâris b. Saîd, İbn Uleyye kadar yakın olmasa da Eyyûb’un talebelerindendir. Benzer şekilde Vüheyb de Eyyûb'un talebeleri içerisinde yer alır. ${ }^{96}$ Buradaki tablodan anlaşılacağı üzere İbn Sîrîn halkası ile irtibatı olan isimler -en azından belli döneme kadar- genellikle hadislerin yazımına onay vermeyen veya en azından "hadisi ezberledikten sonra metni ortadan kaldırıp hafızadan nakletme" tavrını benimseyen kimselerdir.

Öte yandan hadis yazımına taraftar olan isimler içerisinde de Basralı muhaddislerin isimleri yer alır. Burada bir başka halka sahibi Hasan el-Basrî̉nin ${ }^{97}$ yanı sıra Ebû Kılâbe, Muâviye b. Kurre (ö. 113/731), Katâde, ${ }^{98}$ Yûnus b. Ubeyd ${ }^{99}$ ve Süleyman b. Tarhân’’n (ö. 143/761) isimleri anılır. ${ }^{100}$ Bu isimler arasında Yûnus ve Katâde'nin Hasan el-Basrînin yakın talebeleri olması hocalarının hadislerin yazımı konusundaki tavrını sürdürdüklerini gösterir. En azından bu tablo tematik verilerin halka irtibatlarındaki fonksiyonunu görmek açısından önem arzetmektedir. Görüldüğü üzere Basra’daki muhaddisleri yazım tartışmalarında tek bir blok olarak tasvir etmek isabetli olmayıp ${ }^{101}$ aynı dönemde ehl-i hadis içerisinde birden fazla kanaatin var olduğu anlaşılmaktadır.

90 Yahyâ b. Maîn, Min Kelâmi Ebî Zekeriyyâ Yahyâ b. Maîn (Dekkâk), s. 8o; Ahmed b. Hanbel, el-İlel, I, 224, 363; a.mlf., Min Kelâmi'l-İmâm Ebî Abdillâh Ahmed b. Hanbel (Merrûzî), s. 109.

91 İbn Sa'd, et-Tabakāt, VII, 287.

92 Yahyâ b. Maîn, Ma'rifetürr-ricâl, II, 195.

93 Ahmed b. Hanbel, el-îlel, II, 363.

94 Râmhürmüzî, el-Muhaddisül-fâsll, s. 380-81.

95 Râmhürmüzî, el-Muhaddisül-fâsll, s. 371.

96 Ahmed, el-İlel, II, 548.

97 Yahyâ b. Maîn, et-Târîh (Dûrî), IV, 350; a.mlf., Ma'rifetür-ricâl, II, 27; Ahmed b. Hanbel, el-İlel, I, 155, 319. Hasan nüshadan rivayette de bir sorun görmez (Ahmed b. Hanbel, el-ìlel, II, 26o; Cûzcânî, Ahvâlürr-ricâl, s. 193).

98 İbn Sa'd, et-Tabakät, IX, 229.

99 İbn Ebû Hâtim, el-Cerh ve't-ta'dîl, IX, 74 .

100 Râmhürmüzî, el-Muhaddisül-fâsıl, s. 371-75.

101 Basra ehlinin yazım karşıtlığı üzerinde duran Cook’un kanaati bu açıdan revizyona muhtaçtır ("The Opponents of the Writing", s. 444-53). Bu tutumun bir benzeri klasik kaynaklarda da görülebilir. Nitekim İbn Ebû Şeybe meseleyi el-Musannef te "Hadis Yazımına Ruhsat Verenler" ve "Hadis Yazımını Hoş Görmeyenler" başlıklarında ele alır (XIII, 460-67). Ancak her iki başlıkta da İbn Sîrîn'den birer nakle yer 
Halka tespitinde başvurulacak bir diğer tematik veri bidatçılara karşı tutumdur. Bidatçılardan bilgi alınmaması gerektiğini söyleyen ${ }^{102}$ ve ders meclisinden bir bidatçıyı kovan ${ }^{103}$ İbn Sîrîn'in bu tavrını talebeleri sürdürmüştür. Nitekim talebelerini Mürciî Talk b. Habîb’in yanına gitmemeleri konusunda uyaran ${ }^{104}$ Eyyûb, kendisine soru soran bir bidatçıyı terslemiştir. ${ }^{105}$ Öte yandan Hasan ile onun halkasından bazı isimlerin bidatçlık ithamlarına maruz kaldıkları görülür. Hasan hakkındaki Kaderîlik ithamı çağdaşlarınca bilinmektedir. Nitekim bu konudaki tavrı Eyyûb tarafından tepkiyle karşılanmış ve devlet yetkililerine şikâyetle tehdit edilmiştir. ${ }^{106}$ Katâde de Kaderîlik'le itham edilmiştir. ${ }^{107}$ Talebelerinden Saîd b. Ebû Arûbe, Hişâm ed-Destüvâî ve Hemmâm b. Yahyâ da aynı şekilde Kaderîlik'le müttehemdirler. ${ }^{108}$ Dolayısıyla bidat meselesindeki tutumun da halka devamlılığını takip etmek açısından işlevsel olduğu söylenebilir. Bununla birlikte hocaların itikadî temayüllerinin her zaman talebeleri tarafından benimsendiğini söylemek mümkün değildir. Nitekim Hasan halkasından Yûnus b. Ubeyd'in, Amr b. Ubeyd ve ashabına karşı olan sert tutumu buna örnek verilebilir. ${ }^{109}$ Bundan dolayı diğer bilgi türlerinde olduğu gibi tematik veriler de isnad verileri ve rical kaynaklarındaki bilgilerle birlikte değerlendirilmelidir.

Dönemin tartışmalı konularından olan bir meselede şahsi reyin kullanımına dair tutumlar da halka inşasında kullanılabilir. Sadece duyduklarını naklettiğini ve rey kullanmadığını ifade eden İbn Sîrîn'in ${ }^{110}$ tutumunu sürdüren talebesi Eyyûb, ${ }^{111}$ kendisinden reyiyle cevap isteyen bir öğrencisini

verir. Buna göre İbn Sîrîn yazıma hem ruhsat vermekte hem de karşı çıkmaktadır. Halbuki rivayetlere bakıldığında İbn Sîrîn'in ruhsat rivayetinde, "Abîde’ye hadislerin etrafını götürür ve onları sorardım" (XIII, 463), yasaklama rivayetinde ise "İsrâiloğulları atalarından miras kalan birtakım kitaplardan dolayı saptılar" (XIII, 465) dediği görülür. Bu iki rivayet İbn Sîrîn ve talebelerinden gelen diğer nakillerle birlikte düşünüldüğünde, "hadislerin ezberlenene kadar yazıldığı sonradan ortadan kaldırıldığı" ve yazım karșıtlığındaki temel meselenin ise hadislerin, ilim taliplerinin ellerinde dolaşacak şekilde yazılı metinlerde derlenmesi olduğu anlaşılmaktadır.

102 Zehebî, A 'lâmü̉n-nübelâ’, IV, 611.

103 İbn Sa'd, et-Tabakāt, IX, 196.

104 İbn Sa'd, et-Tabakāt, IX, 226.

105 Zehebî, A 'lâmün-nübelâ’, VI, 21.

106 İbn Sa'd, et-Tabakāt, IX, 168.

107 Fesevî, el-Ma'rife, II, 281.

108 Yahyâ b. Maîn, Min Kelâmi Ebî Zekeriyyâ Yahyâ b. Maîn (Dekkâk), s. 97-98.

109 Mizzî, Tehzîbüll-Kemâl, XXXII, 527, 528, 530-31.

110 Ahmed b. Hanbel, el-ïlel, III, 490.

111 Ebû Züra, Târîh, s. 225. 
azarlamıştır. ${ }^{112}$ Hatta Basra’ya gelen Hammâd b. Ebû Süleyman’a (ö. 120/738) hiçbir talebesinin gitmemesini salık vermiştir. ${ }^{13}$

Halkaların inşasında başvurulan tematik veriler, diğer halkalara dair meseleyi takip etmeye imkân verecek verilerin olmaması sebebiyle genel olarak İbn Sîrîn ve Hasan el-Basrî halkalarında yoğunlaşmıştır. Yukarıda görüldügü gibi kurucu hocanın ortaya koyduğu tavrın ve tutumun bütün halka tarafından sürdürülmediği durumlar bulunmaktadır. Bundan dolayı sadece tematik veriler üzerinden halka hakkında yargıya varmak yerine bu tarz bilgileri diğer bilgilerle birlikte değerlendirmek, onları aslî değil takviye edici veriler olarak görmek çok daha doğru olacaktır.

\section{Tartışma ve Sonuç}

Halka tespitinin ne şekilde yapılabileceği meselesinin, en azından incelenen II. (VIII.) asrın ilk yarısındaki Basra hadis halkaları özelindeki metodik bir sunumu karşımıza şu tabloyu çıkarmaktadır:

\section{Tablo 1: Basra Hadis Halkaları}

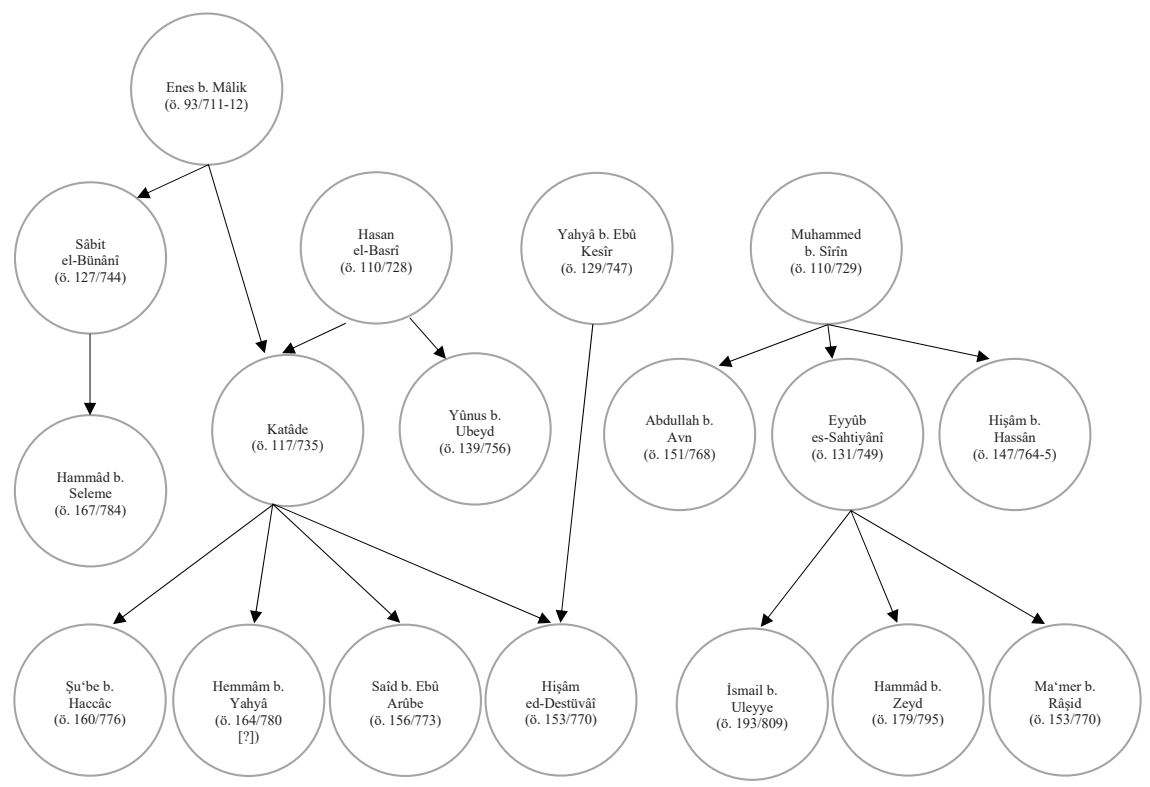

112 İbn Sa'd, et-Tabakāt, IX, 247; Yahyâ b. Maîn, Ma'rifetürr-ricâl, II, 18o.

113 İbn Sa'd, et-Tabakāt, IX, 287. 
Basra ilim geleneğinin büyük oranda Medine’ye dayandığı daha önce ifade edildiği için burada Hasan el-Basrî, İbn Sîrîn, Katâde, Yahyâ b. Ebû Kesîr ve Eyyûb’un Medineli kaynakları tabloya yansıtılmamıștır.

Makalenin veri çıktısının sunumunun ardından halka bilgisinin hadis tarihini anlamaya yönelik katkıları incelenebilir. Yukarıda örnekleri gösterildiği üzere rical ve usul kaynaklarında dağınık olarak yer alan pek çok bilgi makul bir tarihî çerçeveye oturtulmadığı sürece aslında pek de anlamlı durmamaktadır. Hatta klasik kaynaklarda yer alan ve çoğu araştırmada sözlük anlamı verilerek geçilen pek çok kelimenin aslında ciddi hususları imleyen birer kavram olduğu da ancak halka bilgisiyle anlamlı hale gelmekte ve hadis tarihi açısından kullanılabilir bir mahiyet arzedebilmektedir. İsnadlar üzerinden yapilan halka tespiti ile birlikte mezkûr bilgiler yeni bir hadis tarihi yazımının veri alt yapısını teşkil edebilecektir. Şöyle ki, şu ana kadar hadis tarihi bağlamında yapılan anlatılar şehir veya bölgeleri kısmen gündemine almakta, ancak ekollerin bölgesel farklılıklarını ya da tarihî süreçteki değişimlerini ise genellikle göz ardı etmektedir. Bundan dolayı ehl-i hadis statik bir yapı olarak sunulmakta ve II (VIII) ve III. (IX.) asırlarda değişen tartışma konuları, muhataplar, tenkit dili, eser üretim tarzları bir türlü tarihî bir çerçeveye yerleştirilememekte ve dolayısıyla sürekli olarak anakronik yorumlara gidilmektedir. Ehl-i hadisin dönemsel ve bölgesel değişimlerine dikkat edilmediği gibi onların kendi içindeki mesleki eğilimleri de bir türlü gündeme getirilememektedir. Hem isnad verilerini hadis tarihi açısından aktif olarak kullanmayı öneren hem de rical ve usul kaynaklarındaki verileri makul bir çerçeveye yerleştirmeyi hedefleyen bu metotla birlikte yeni bir tarih anlatısı yapmanın yolu açlacaktır.

Halka tespitinin tarih yazımına sağlayacağı en önemli katkı ehl-i hadisin farklı gruplardan müteşekkil bir yapı olduğunu göstermesi olacaktır. İleride Kûfe, Dımaşk, Yemen ve Hicaz halkalarının da tarihsel kayıtlar gözetilerek netleştirilmesiyle ehl-i hadisin bölgesel olarak farklı tavırlar taşıdığı, hatta tek bir şehirde bile farklı temayüllere sahip ehl-i hadis gruplarından bahsedilebileceği görülecektir. Belki bu tespitin ardından belirli bir şehirdeki ehl-i hadis halkalarının dahi bazı noktalarda farklı düşünce tarzlarına sahip olduğu anlaşllacak ve böylece şehirlerdeki ilim gelenekleri daha rahat bir şekilde takip edilebilecektir. Böylece bir ehl-i hadis monografisi yazımı için gerekli veri malzemesi büyük oranda temin edilmiş olacaktır.

Hangi tartışma konusunun hangi dönem ve şehirde kimler tarafından mesele edildiğini tespit etmek, aslında o konunun kayıtlarını görmeye imkân verecektir. Makalede gösterildiği üzere kitâbetü'l-hadîs, ehl-i bidat gruplarıyla temaslar ya da kısmen temas edilen manen rivayet gibi meselelerde veya 
burada incelenmeyen namazda ellerin kaldırılması, nebîz tartışmaları, besmelenin cehrî okunması, haddesenâ/ahberanâ lafızlarının kullanımı, tafdil tartışmaları ve siyasilerle ilişkiler gibi konular incelenirken tarihî ve coğrafi kayitlar olmadan hareket etmek oldukça ciddi bir risktir ve her zaman genellemelere dayalı yargılara sebep olan metodik bir hatadır. Halka bilgisiyle hareket edildiği zaman ise mesele hem tarihî bir devamlllığa hem de bölgesel olarak birtakım kayıtlara kavuşturulmuş olmaktadır. Bu durum ise incelenen meseleyi "kendinde inceleme"nin, yani gerçekleştiği zamanda ve zeminde ele almanın yolunu açmaktadır.

İncelenen dönem ve coğrafyada hayli makul sonuçlar veren metodun diğer dönemlerde ve coğrafyalarda kullanımının risklerine de burada temas edilmelidir. Nitekim Dımaşk hadis halkaları çalışılırken isnad verilerinin tespitinde Basra ya da Kûfe'de olduğu gibi Abdürrezzâk ve İbn Ebû Şeybe’nin el-Musannefleri ile Ahmed b. Hanbel'in el-Müsned' inin istenilen sonucu vermesi mümkün değildir. Bundan dolayı Taberânînin (ö. 360/971) Müsnedüş̧Şâmiyyîn'i ilgili coğrafya açısından çok daha işlevseldir. Benzer şekilde Yemen hadis halkaları için Abdürrezzâk’̉n eserinin çok daha merkeze yerleşeceği rahatlıkla öngörülebilir. Dolayısıyla değişen coğrafya ile isnad taramasının yapılacağı temel kaynaklar değişkenlik gösterecektir. Aynı durum kısmen rical kaynakları açısından da söz konusudur. Nitekim Ahmed b. Hanbel ya da Yahyâ b. Maîn'in ricale dair eserleri Basra ve Kûfe ilmî birikimini etraflıca sunuyorsa da Dımaşk ders halkalarının inşasında ancak bir yere kadar işlevseldir. Bundan dolayı Dımaşk için mesela Ebû Züra ed-Dımaşkỉnin (ö. 281/894) Târîh'i ve İbn Asâkir'in (ö. 571/1176) Târîhu medîneti Dımaşk’’ büyük önem arzetmektedir.

Metot etrafında akla gelebilecek bir diğer sorun dönem değişikliklerinde metodun işlevini icra edip edemeyeceğidir. II. (VIII.) asrın ilk yarısında gözlemlenen dinamikler ile ikinci yarısında gözlemlenen dinamikler arasında ciddi farklar söz konusudur. Şöyle ki, ilk dönemde siyasi sahadaki değişiklikler, fetihler ve dolayısıyla İslam toplumunun yapısının değişim göstermesi, ekollerin çerçevesinin netleşmeye başlaması, hayatın akışı içerisinde devam edegelen bir olgu olan rivayet eyleminin peyderpey sistemli bir hale gelmesi, semâ, cerh-ta'dil ve müzakere meclislerinin ortaya çıkması, yazı malzemesinin değişimi, rihlelerin gitgide daha düzenli bir hal alması gibi olgular dikkat çekmektedir. Aynı asrın ikinci yarısında ise hem çok daha oturmuş bir siyasi iktidar ve ilim yapma tarzı vardır hem de ekoller arasındaki ilişkiler daha farklı bir surette yeniden şekillenmektedir. Yalnızca bir şehirdeki bir ya da birkaç hoca ile yetinerek ilim yapma anlayışının hâkim olduğu ve şehir amellerinin ileri düzeyde önem arzettiği II. (VIII.) asrın ilk yarısında 
bu metot işlevsel ise de düzenli rihlelerle şehir amellerinin zayıfladığı ve her bir şehrin rivayet birikimine artık farklı şehirlerde de ulaşılabildiği II. (VIII.) asrın ikinci yarısı farklı değerlendirilmek durumundadır. Benzer şekilde ihtisas halkalarının şehir ve bölgelerdeki gelişim seyrinin farklılığı açık olmakla birlikte dönemsel olarak da II. (VIII.) asrın ikinci yarısının kendine özgü dinamikleri dikkate alınmalıdır.

Burada dile getirilen iki temel eleştiri noktasına rağmen üzerinde çalış1lan metot en azından II. (VIII.) asrın ilk yarısında tutarlı sonuçlara ulaşma imkânı sunmaktadır. Coğrafya ve dönem değişikliklerinde ise metodun gerekli revizyonlarla yeniden sinanması gerekmektedir. Ancak yapılacak revizyonların bu üç aşamalı metot teklifinin ana unsurlarını zayıflatmayacağı ve metodun, hedeflediği verileri sunma açısından olabildiğince tutarlı sonuçlar verdiği düşünülmektedir.

\section{Bibliyografya}

Abdürrezzâk es-Sanânî, el-Musannef, nşr. Habîbürrahmân el-A'zamî, I-XII, Beyrut: elMektebü'l-İslâmî, 1983.

Ahmed b. Hanbel, el-İlel ve ma'rifetürr-ricâl, nşr. Vasiyyullah b. Muhammed Abbas, I-IV, Riyad: Dârü'l-Hânî, 1422/2001.

Ahmed b. Hanbel, Min Kelâmi'l-İmâm Ebî Abdillâh Ahmed b. Hanbel fî̀ ileli'l-hadîs ve ma'rifetìr-ricâl (Meymûnî), nşr. Subhî es-Sâmerrâî, Riyad: Mektebetü’l-maârif, 1409/1988, s. 151-203.

Ahmed b. Hanbel, Min Kelâmi'l-İmâm Ebî Abdillâh Ahmed b. Hanbel fî ileli'l-hadîs ve ma'rifetìr-ricâl (Merrûzî), nşr. Subhî es-Sâmerrâî, Riyad: Mektebetü’l-maârif, 1409/1988, s. 31-130.

Ahmed b. Hanbel, el-Müsned, nşr. Şuayb el-Arnaût v.dğr., I-LII, Beyrut: er-Risâletü’lâlemiyye, 1436/2015.

Ahmed b. Hanbel, Suâlâtü Ebî Dâvûd li'l-İmâm Ahmed b. Hanbel fî cerhi'r-ruvât ve ta'dîlihim, nşr. Ebû Ömer Muhammed b. Ali el-Ezherî, Kahire: el-Fârûku’l-hadîse li’ttıbâa ve’n-neşr, 1431/2010.

Akgün, Hüseyin, Hadis Rivâyet Coğrafyası (Hicrî İlk 150 Yll), İstanbul: İFAV, 2019.

Ali b. Medînî, İlelül-hadîs ve ma'rifetür-ricâl ve’t-târîh, nşr. Mâzin b. Muhammed esSirsâvî, Demmâm: Dâru İbni'l-Cevzî, 2011.

Ali b. Medînî, Suâlâtü Muhammed b. Osmân b. Ebî Şeybe li-Alî b. el-Medînî fi'l-cerh ve’tta dîl, nşr. Muvaffak b. Abdullah b. Abdülkādir, Riyad: Mektebetü’l-maârif, 1404/1984.

Âşıkkutlu, Emin, "Bir İsnad Tenkid Yöntemi Olarak Şartlı Cerh-Ta‘diller ve Uygulamadaki Sonuçları”, Marmara Üniversitesi İlâhiyat Fakültesi Dergisi, 20 (2001): 49-80.

Aydın, Nevzat, Hadis Metodolojisi Üzerine Düşünmek: İmam Evzainin Hadis Metodu Özelinde, Trabzon: Kalem Yayınevi, 2011. 
Brown, Jonathan A. C., "Did the Prophet Say It or Not? The Literal, Historical, and Effective Truth of Hadiths in Early Sunnism", Journal of the American Oriental Society, 139/2 (2009): 259-85.

Buhârî, Muhammed b. İsmâil, el-Câmiu’s-sahîh, nşr. Şuayb el-Arnaût - Âdil Mürşîd, I-V, Dımaşk: er-Risâletü'l-âlemiyye, 1432/2011.

Buhârî, Muhammed b. İsmâil, et-Târîhu'l-kebîr, I-XII, Beyrut: Dârül-kütübi'l-ilmiyye, t.y.

Cohen, Hayyim J., "The Economic Background and the Secular Occupations of Muslim Jurisprudence and Traditionalists in the Classical Period of Islam (Until the Middle of the $11^{\text {th }}$ Century)", Journal of Economic and Social History of the Orient, 13/1 (1970): $16-61$.

Cook, Michael, “The Opponents of the Writing of Tradition in Early Islam”, Arabica, 44/4 (1997): 437-530.

Cûzcânî, Ebû İshak, Ahvâlürr-ricâl, nşr. Subhî el-Bedrî es-Sâmerrâî, Beyrut: Müessesetürrisâle, 1405/1985.

Çelik, Ali, İlk Üç Asırda Basra'da Hadis İlmi (doktora tezi), Kahramanmaraş Sütçü İmam Üniversitesi Sosyal Bilimler Enstitüsü, 2017.

Ebû Dâvûd es-Sicistânî, Suâlâtü Ebî Ubeyd el-Âcurrî li'l-İmâm Ebî Dâvûd es-Sicistânî fî ma'rifetîr-ricâl ve cerhihim ve ta'dîlihim, nşr. Ebû Ömer Muhammed b. Ali el-Ezherî, Kahire: el-Fârûku'l-hadîse li't-tıbâa ve’n-neşr, 1431/2010.

Ebû Züra ed-Dımaşkī, Târîh, nşr. Halîl el-Mansûr, Beyrut: Dârü'l-kütübi'l-ilmiyye, $1417 / 1996$.

Fesevî, el-Ma'rife ve't-târîh, nşr. Ekrem Ziyâ el-Ömerî, I-IV, Medine: Mektebetü'd-dâr, $1410 / 1990$.

Gürler, Kadir, Ehl-i Hadisin Düşünce Yapısı: İlk Dönem Ehl-i Hadis Örneği, Bursa: Emin Yayınları, 2007.

Hallaq, Wael B., Origins and Evolution of Islamic Law, Cambridge: Cambridge University Press, 2005.

Hatîb el-Bağdâdî, el-Kifâye fî ma'rifeti usûli ilmìr-rivâye, nşr. Ebû İshak İbrâhim b. Mustafa Âlü Bahbah ed-Dimyâtî, I-II, Semennûd: Mektebetü İbn Abbâs, 2002.

İbn Adî, el-Kâmil fî duafâirr-ricâl, nşr. Âdil Ahmed Abdülmevcûd v.dğr., I-IX, Beyrut: Dârü'l-kütübi'l-ilmiyye, t.y.

İbn Ebû Hâtim, el-Cerh ve't-ta'dîl, nşr. Mustafa Abdülkādir Atâ, I-X, Beyrut: Dârü’lkütübi'l-ilmiyye, 1422/2010.

İbn Ebû Şeybe, Ebû Bekir, el-Musannef, nşr. M. Avvâme, I-XXVI, Cidde: Dârüll-kıble li’ssekāfeti'l-İslâmiyye, 2010.

İbn Hacer el-Askalânî, Tehzîbü't-Tehzîb, nşr. Halîl Me’mûn Şîhâ v.dğr., I-VI, Beyrut: Dârü'l-ma'rife, 1417/1996.

İbn Hibbân, es-Sikāt, I-X, Haydarâbâd: Dâiretü'l-maârifi'l-Osmâniyye, 1393-99/1973-79.

İbn Receb, Şerhu İlelit-Tirmizî, nşr. Nûreddin Itr, I-II, Dımaşk: Dârü’l-Beyrûtî, 2007.

İbn Sa'd, et-Tabakātü’l-kübrâ, nşr. Ali M. Ömer, I-X, Kahire: Mektebetül-Hancî, 1421/2001.

İclî, Ebü'l-Hasan, Ma'rifetüs-sikāt, nşr. Abdülalîm Abdülazîm el-Bestevî, I-II, Medine: Mektebetü’d-dâr, 1405/1985. 
Kahraman, Hüseyin, Kûfe'de Hadis (İlk Üç Asır), Bursa: Emin Yayınları, 2006.

Kurbaşoğlu, M. Hayri, Ehl-i Sünnet' in Kurucu Ataları: Ashabu'l-hadise Göre Allahin Sıfatları Meselesi, Ankara: OTTO, 2011.

Kutlu, Sönmez, Selefiliğin Fikrî Arka Planı: İslam Düşüncesinde İlk Gelenekçiler, Ankara: OTTO, 2017.

Kuzâh, Emîn, Medresetü'l-hadîs fi'l-Basra hatte'l-karni's-sâlisi'l-hicrî, Beyrut: Dâru İbn Hazm, 1419/1998.

Kuzudişli, Bekir, Hadis Tarihi, İstanbul: Kayıhan Yayınları, 2017.

Lucas, Scott C., "Where are the Legal Hadìth?" A Study of the "Muṣannaf" of Ibn Abī Shayba", Islamic Law and Society, 15/3 (2008): 284-314.

Maden, Ömer Faruk, Hicrî II. Asır Ehl-i Hadîs Halkaları: Basra Örneği (yüksek lisans tezi), Marmara Üniversitesi Sosyal Bilimler Enstitüsü, 2018.

Makdisi, George, Ortaçağ’da Yüksek Öğretim: İslâm Dünyası ve Hıristiyan Batı, çev. Ali Hakan Çavuşoğlu - Tuncay Başoğlu, İstanbul: Klasik, 2012.

Melchert, Christopher, "Hanefîliğin Kûfe ve Ehl-i Hadis'in Medine Kökenli Olarak Algılanması", Sünni Düşüncenin Teşekkülü: Din-Yorum-Dindarlık, der. ve çev. Ali Hakan Çavuşoğlu, İstanbul: Klasik, 2018, s. 167-204.

Melchert, Christopher, The Formation of the Sunni Schools of Law, 9th-10th Centuries C.E.., Leiden: Brill, 1997.

Mizzî, Yûsuf b. Abdurrahman, Tehzîbü'l-Kemâl, nşr. Beşşâr Avvâd Ma'rûf, I-XXXV, Beyrut: Müessesetürr-risâle, 1403-13/1982-1992.

Özkan, Halit, Hicrî İlk İki Asırda Farklı Şehirlerde Amel Telakkisi Oluşumunda Sünnet ve Hadisin Yeri (doktora tezi), Marmara Üniversitesi Sosyal Bilimler Enstitüsü, 2006.

Özşenel, Mehmet, İlk Dönem Hadis-Rey Tartışmaları: Şeybânî Örneği, İstanbul: İFAV, 2015. Râmhürmüzî, el-Muhaddisü̉l-fâsıl, nşr. M. Acâc el-Hatîb, Beyrut: Dârül-fikr, 1391/1971.

Romanov, Maxim, https://maximromanov.github.io/2014/08-23.html (erişim: 17.06.2020).

Sarmini, Mohamad Anas, "el-Mufâdale beyne'r-ruvât bi-lafzi "fûlân ehabbü ileyye" inde nukkādi'l-hadîs”, Bülent Ecevit Üniversitesi İlahiyat Fakültesi Dergisi, 6/2 (2019): 367 84.

Spectorsky, Susan, "Ḥadīth in the Responses of Isḥāq b. Rāhwayh", Islamic Law and Society, 8/3 (2001): 407-31.

Süyûtî, Tedrîbürr-râvî, nşr. M. Avvâme, I-IV, Medine: Dârü'l-yüsr - Cidde: Dârü’l-minhâc, $1437 / 2016$.

Topgül, Muhammed Enes, "Erken Dönem İslam Tarihinde İlim Merkezleri ve Ulema Hareketliliğinin Tespiti Üzerine Metodolojik Bir Arayıș: Nisbeler", Dîvân: Disiplinlerarası Çalışmalar Dergisi, 42 (2017): 1-31.

Topgül, Muhammed Enes, İsnâdın Satır Araları, İstanbul: İFAV, 2018.

Turhan, Halil İbrahim, Ricâl Tenkidinin Doğuşu ve Gelişimi: Hicrî İlk İki Asır, İstanbul: İFAV, 2015.

Watt, W. Montgomery, İslâm Düşüncesinin Teşekkül Devri, çev. Ethem Ruhi Fığlalı, Ankara: Sarkaç Yayınları, t.y. 
Yahyâ b. Maîn, Ma'rifetürr-ricâl, nşr. M. Kâmil el-Kassâr v.dğr., I-II, Dımaşk: Matbûâtü Mecmai'l-lugati'l-Arabiyye, 1405/1985.

Yahyâ b. Maîn, Min Kelâmi Ebî Zekeriyyâ Yahyâ b. Maîn rivâyetü Ebî Hâlid ed-Dekkāk, nşr. Ahmed M. Nûrseyf, Dımaşk: Dârü'l-Me’mûn li't-türâs, t.y.

Yahyâ b. Maîn, Suâlâtü Ebî İshak İbrâhim b. el-Cüneyd li'l-İmâm Yahyâ b. Maîn fi'l-cerh ve’tta'dîl ve ileli'l-hadîs, nşr. Ebû Ömer Muhammed b. Ali el-Ezherî, Kahire: el-Fârûku’lhadîse li't-tıbâa ve’n-neşr, 2007.

Yahyâ b. Maîn, Suâlâtü Osmân b. Tâlût el-Basrî̀ lỉ-İmâm Ebî Zekeriyyâ Yahyâ b. Maîn, nşr. Ebû Ömer Muhammed b. Ali el-Ezherî, Kahire: el-Fârûku'l-hadîse li’t-tıbâa ve’n-neşr, $1428 / 2007$.

Yahyâ b. Maîn, et-Târîh (Dûrî), nşr. Ahmed M. Nûrseyf, I-IV, Mekke: Merkezü'l-bahsi'lilmî ve ihyâi't-türâsi'l-İ́slâmî, 1399/1979.

Yahyâ b. Maîn, Târîh (Dârimî): Târîhu Osmân b. Saîd ed-Dârimî an Ebî Zekeriyyâ Yahyâ b. Maîn fî̀ tecrîhìr-ruvât ve ta'dîlihim, nşr. Ahmed M. Nurseyf, Dımaşk: Dârü’l-Me’mûn li't-türâs, 1980.

Yıldız, Fahreddin, İlmî Bir Disiplin Olarak Fıkhü'l-Hadîs (doktora tezi), Marmara Üniversitesi Sosyal Bilimler Enstitüsü, 2016.

Zehebî, Siyeru a lâmi’n-nübelâ’, nşr. Şuayb el-Arnaût v.dğr., I-XXX, Beyrut: Müessesetü’rrisâle, $1432 / 2011$.

\section{A Proposal for a Methodology of Determining Scholarly Circles of Ahl al-Ha- dith: The Case of Basra During the First Half of the $2^{\text {nd }} / 8^{\text {th }}$ Century}

This paper explores the regional and local differences among ahl al-hadith and proposes a methodology to identify and detail hadith circles in the early prominent cities (amșār). By distinguishing varieties of ahl al-hadith, scholars may produce more accurate narratives on the history of the hadith. The paper focuses on Bașra, one of the most important centers of learning during the $2^{\text {nd }} / 8^{\text {th }}$ century, together with Medina and Küfa. It examines in three stages the data in the hadìth collections, biographical dictionaries (rijäl books), and books of hadith methodology.

Firstly, by examining the 1,500 narrators who lived in Bașra during the $2^{\text {nd }} / 8^{\text {th }}$ century, we determine a master set of narrators on which isnād data will be based. It primarily utilizes rijäl books that were arranged on the basis of geography. We examine in detail major rijāl books such as Ibn Sa'd's al-Ṭabaqāt, Yahyā b. Ma'īn's al-Tārīkh, Khalīfa b. Khayyāṭ’s al-Ṭabaqāt, Aḥmad b. Ḥanbal's al-'Ilal, and Abū Dāwūd's Su'ālāt. Based on the data given in these sources, we have reached a master set of 900 narrators. By examining teacher-student relationships of all transmitters, we identify 23 narrators who were cited the most. In order to verify this, we analyze al-Mizzī's Tahdhīb al-Kamāl to identify the teacher-student relationships of 49 random narrators from the successor (täbi ün) generation downward, and then the 30 most frequently cited transmitters. Following this, we check the metadata of transmission in the sources that contain numerous narrations and reflect mostly transmission networks based in Iraq such as 
Aḥmad b. Ḥanbal's al-Musnad, 'Abd al-Razzāq b. Hammām, and Ibn Abī Shayba’s al-Mușannaf. At the end, the number of narrators falls from 30 to 21, thereby identifying the narrators most active in hadìth circles.

Based on this narrow set of narrators, it seems that the tradition of hadith in Basra was generally based on Medina and specifically on Abū Hurayra, contrary to the common assumption that it was based on the companions who came to Basra after its conquest. In other words, the foundational generation that played a role in the transmission of hadith in Basra seems to have been the successors, but not the companions. Among them, the circles of al-Hasan al-Bașrī, Muhammad b. Sīrīn, Thābit al-Bunānī, and Yahyā b. Abī Kathīr stood out. According to this, Qatāda b. Di'āma and Yūnus b. 'Ubayd were the closest students of al-Ḥasan alBașrī, whose scholarly origins is difficult to determine; after him, Qatāda led the circle. Muhammad b. Sīrin transmitted from his teacher Abū Hurayra most of his teachings and his closest students were Ayyūb al-Sakhtiyānī, 'Abdullāh b. 'Awn, and Hishām b. Hassān; then his circle was led by Ayyūb. Thābit's closest teacher was Anas b. Mālik who transmitted hadìth semi-systematically and his closest student was Hammād b. Salama. Lastly, Yahyyā’s closest teacher was Medinese Abū Salama b. 'Abd al-Raḥmān and his closest students were Hishām al-Dastuwā’i and Damascene al-Awzāi $\bar{i}$. As seen here, the successor's knowledge of hadìth depended on the Medinan network.

Next, we compare results derived from transmission data with the historical information and rijāl books. I examine the information in the rijāl books in two subsections as primary and secondary data. Primary data includes information showing teacher-student relations. As examples for primary data, we can count the information on who led the scholarly circle after a teacher, the emphasis on the length of time a transmitter passed with his teacher, and a student's acknowledgement of his teacher's role in his acquisitions of knowledge or vice versa. In addition, we can mention here certain concepts indicating close teacherstudent relations such as șāhib-aṣhāb-șahiba, jalīs-jalasa ilā-mujālasa, ikhtalafa ilā, arwā al-nās, awthaq al-nās, ahfaz al-nās, a'lam al-nās, athbat al-nās, and asnad al$n \bar{a} s$ as well as some expressions of the critics indicating hierarchical relationships between teachers and students such as fulān ahabbu ilayya min fulān fì hadìthi fulān/fí fulān. Secondary data comprises of information that illuminates personal connections between teachers and students. We count as examples for the secondary data a student's description of his teacher's physical or psychological conditions and his account of various kinds of secondary information on his relations with his teacher. Although this information might seem unimportant at first, we make use of this data for determining who was associated with the circles. In comparing data of transmission with the information provided by rijäl books, we observe a concurrence between the two.

Finally, we compare the results derived from hadith collections and rijäl books with the books on hadith methodology. As the books on methodology are organized by subject, the opinions of some scholars on issues related to the transmission of hadith are mostly listed together. When we examine the results mentioned above in order to determine scholarly circles, we observe that all results are verified by 
methodology books. The circle of Ibn Sīin had negative opinions on the issue of transmission by the general meaning (al-riwāya bi al-ma'nā) and the writing down of hadīth (kitābat al-ḥadìth), whereas the circle of al-Hasan held positive opinions. In respect to relations with innovators (ahl al-bid'a), the Ibn Sīrīn's circle held extremely negative attitudes, whereas al-Hasan al-Bașrî’s circle, especially al-Hasan and his student Qatāda, were accused of being Qadarite. On the use of personal judgment-another issue of dispute at that time-Muhammad b. Sirin and his students maintained distance. We observe nevertheless that there are some exceptions and one should not depend solely on this data.

This paper draws attention to the importance of treating the history of hadith in a more nuanced manner by integrating temporal and spatial elements into its large narrative. It also argues that the information in hadith collections, rijäl, and methodology books concur with each other when they are examined with a balanced perspective. If one examines the data in one kind of source alone, one may reach incorrect conclusions. In short, this method seems to produce largely consistent results in determining scholarly circles for transmission of hadith in the prominent cities during the first half of the second century.

Keywords: Ahl al-ḥadīth, ḥadìth, Basra, scholarly circle, al-Ḥasan al-Bașrī, Muhammad b. Sīrīn. 